\title{
Hydrogeology of the
}

Huntington-Smithtown area Suffolk County, New York

By E. R. LUBKE

CONTRIBUTIONS TO THE HYDROLOGY OF THE UNITED STATES

GEOLOGICAL SURVEY WATER-SUPPLY PAPER 1669-D

Prepared in cooperation with the Suffolk County Board of Supervisors, the Suffolk County Water Authority, and the New York Water Resources Commission

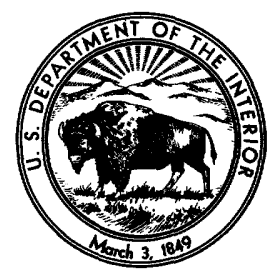




\section{UNITED STATES DEPARTMENT OF THE INTERIOR}

STEWART L. UDALL, Secretary

\section{GEOLOGIGAL SURVEY}

Thomas B. Nolan, Director 


\section{CONTENTS}

\begin{tabular}{|c|c|}
\hline & Page \\
\hline$\ldots$ & D1 \\
\hline troduction. & 3 \\
\hline Scope and purpose of investigation & 3 \\
\hline Location and extent of area & 3 \\
\hline Previous investigations. & 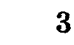 \\
\hline Acknowledgments & \\
\hline Well-numbering system & 5 \\
\hline eography & 6 \\
\hline Physiography and drainage & 6 \\
\hline Culture & 7 \\
\hline Climate & 8 \\
\hline eologic formations and their water-bearing character & 9 \\
\hline features & 9 \\
\hline Bedrock & 10 \\
\hline Upper Cretaceous series & 11 \\
\hline Raritan formation & 12 \\
\hline Magothy(?) formation & 13 \\
\hline Pliocene(?) series & 19 \\
\hline gravel & 19 \\
\hline ( & 20 \\
\hline Undifferentiated deposits of Pleistocene and Pliocene(?) age & 23 \\
\hline Upper Pleistocene deposits & 25 \\
\hline Recent series & 27 \\
\hline ( & 27 \\
\hline ing units & 27 \\
\hline ed ground-water bodies. & 28 \\
\hline Shallow aquifer & 28 \\
\hline Intermediate aquifer & 33 \\
\hline Deep aquifer & 36 \\
\hline Recharge & 40 \\
\hline 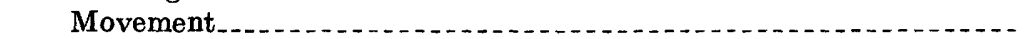 & 41 \\
\hline ( & 44 \\
\hline ( & 45 \\
\hline 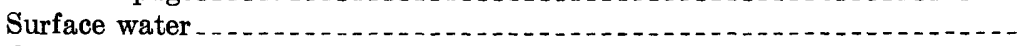 & 48 \\
\hline Chemical quality & 49 \\
\hline Temperature & 52 \\
\hline Contamination & 52 \\
\hline Conclusions............ & 57 \\
\hline eferences cited...... & 64 \\
\hline dex & 67 \\
\hline
\end{tabular}




\section{ILLUSTRATIONS}

[Plates are in pocket]

Plate 1. Well-location map.

2. Geologic map.

3. Contour map of buried Cretaceous surface.

4. Geologic sections.

5. Water-table contour map.

6. Distribution of public supply and industrial pumping.

FIGURE 1. Index map

3. Map of clay unit of Smithtown

4. Hydrographs of four wells .

5. Hydrographs of two wells and monthly precipitation....... 32

6. Piezometric contour map of intermediate aquifer .......... 34

7. Hydrogeologic section at South Huntington

8. Hydrographs of wells in the shallow and intermediate aquifers_ $\quad 37$

9. Piezometric contour map of deep aquifer . . 39

10. Hydraulic profile $X-X^{\prime} \ldots \ldots$

11. Withdrawals from public-supply systems .

12. Map of sites for temperature and chloride determainations..... $\quad 53$

\section{TABLES}

TABLE 1. Summary of average monthly and annual precipitation at stations in or adjacent to the Huntington-Smithtown area......

2. Summary of the stratigraphy and water-bearing properties of the deposits underlying the Huntington-Smithtown area, Suffolk County, N.Y.

3. Estimated permeability of water-bearing material in the Magothy(?) formation and Pleistocene deposits

4. Summary of average discharge of streams continuously or occasionally gaged by the U.S. Geological Survey in the Huntington-Smithtown area . . . . . . . .

5. Chemical analyses of water from typical wells in the Huntington-Smithtown area . . . . . . . . . . . . . . . . .

6. Iron concentration, chloride concentration, hardness in $\mathrm{CaCO}_{3}$ and variation in $\mathrm{pH}$ of ground water in the HuntingtonSmithtown area, 1956-59

7. Records of selected wells in the Huntington-Smithtown area..- 


\title{
CONTRIBUTIONS TO THE HYDROLOGY OF THE UNITED STATES
}

\section{HYDROGEOLOGY OF THE HUNTINGTON-SMITHTOWN AREA, SUFFOLK COUNTY, NEW YORK}

\author{
By E. R. LUBKe
}

\section{ABSTRACT}

This report presents the results of an investigation of the ground-water resources and related geologic environment of the Huntington-Smithtown area, New York, by the U.S. Geological Survey in cooperation with the Suffolk County Board of Supervisors, the Suffolk County Water Authority, and the New York State Water Resources Commission. Fieldwork on the investigation, which is part of an overall program for the continuing appraisal of the ground-water reservoir of Long Island, N.Y., was carried on between November 1957 and May 1959.

The Fluntington-Smithtown area contains about 153 square miles in northwestern Suffolk County, and the population in 1958 was estimated to be 153,000 . The area is in north-central Long Island, which is the partly submerged northeastern extension of the Atlantic Coastal Plain. The chief physiographic features, which are largely of glacial origin, include a belt of headlands and bays along the margin of Long Island Sound, the Harbor Hill end moraine, an intermorainal belt, the Ronkonkoma terminal moraine and related clusters of hills, and a south-sloping glacial outwash plain. All the larger streams, such as the Nissequogue River, Cold Spring Brook, Sunken Meadow Creek, Stony Hollow Run, and Mill Creek, are perennial and are characterized by markedly uniform fiow sustained by ground-water discharge. The total runoff of these streams has averaged about 11 billion gallons a year during the period of record. The climate is temperate humid with an annual average precipitation of 49 inches. Since World War II, a large growth in population has taken place in the report area, which is suburban to New York City. Concurrently, many new homes have been constructed and light industries have been established. Agriculture, formerly a major activity, is on the wane with the inroads of suburban development on farmed acreage. In 1960 , less than 1,800 acres was farmed.

The Huntington-Smithtown area is underlain by 400 to 1,300 feet of unconsolidated deposits of Cretaceous and Quaternary age resting upon a southeast-sloping bedrock surface. These deposits constitute the ground-water reservoir. Three distinct aquifers have been recognized in the ground-water reservoi.r. These are: (1) a shallow aquifer, which mainly includes permeable upper Pleistocene deposits, the Magothy(?) formation, and possibly some Pliocene deposits; it lies between the water table and about 50 to 80 feet below sea level and contains water generally under unconfined conditions, 
(2) an intermediate aquifer, which extends from about 60 to 100 feet below sea level to 850 feet below sea level in the Pleistocene deposits and in the Magothy(?) formation and which contains water under confined con?itions, (3) a deep aquifer, which is mainly composed of the Lloyd sand member of the Raritan formation and which contains water under confined conditions. In 1957, approximately 53 percent of the gross pumpage was from Pleistocene deposits, 44 percent from the Magothy (?) formation, and 3 percent from the Lloyd sand member.

The average natural recharge to the ground-water reservoir in the Huntington-Smithtown area is estimated to be $147 \mathrm{mgd}$ (million gallons per day). This is equivalent to an average of about 43 percent of the average annual precipitation ( 49 inches) or 21 inches of water. The remainder of the precipitation is returned to the atmosphere by evapotranspiration or is lost to the sea by overland runoff.

In general, ground-water supplies in substantial quantity and of good quality can be obtained from wells almost everywhere in the project area, except locally on Lloyd and Eaton Necks. Between 1932 and 1957, average withdrawals for public supply increased from $1.5 \mathrm{mgd}$ in 1932 to $8.8 \mathrm{mgd}$ in 1957 . In addition, about $5.9 \mathrm{mgd}$ was used in 1957 for industrial, institutional, domestic, and agricultural purposes.

On Lloyd and Eatons Necks, potentialities for ground-water development are limited by a reduced thickness of the ground-water reservoir and the nearness of salt-water bodies, which pose the ever-present threat of contamination. In this regard, Eatons Neck is particularly vulnerable, as salty ground water occurs at varying depth around much of its shoreline. Apparently fresh water in the interior part of Eatons Neck occurs only in the upper Pleistocene deposits and in the upper part of the Magothy(?) formationprobably as a fresh-water lens floating on denser salty water. On the other hand, on Lloyd Neck the ground-water reservoir appears to contain fresh water from the water table to bedrock, except in some marginal parts of the peninsula.

In the main part of the report area, the chief centers of moderately heavy withdrawal from wells are near the southern extremities of Cold Spring and Huntington Harbors, and near Centerport and Northport Harbors. Withdrawals from these centers, exceeding those in 1960 , may result in local contamination from nearby bodies of salt water. The $1960 \mathrm{draft}$ on the ground-water reservoir in the central and southern parts of both Huntington and Smithtown is relatively light. Consequently, these parts would be optimum for new ground-water development. Generally, it would be desirable to locate new wells and well fields at least 2 miles inland from tidewater and a mile from existing installations of moderately heavy withdrawal to lessen the effect of mutual interference between pumping wells.

Contamination of the ground-water reservoir by synthetic detergents and domestic waste was not a problem of large magnitude in the project area in 1060 , but it may intensify in the future if adequate countermeasures are not undertaken. Partial solutions to the problem include: (1) encouragement of the development and marketing of degradable detergents, (2) limiting industrial and residential development in specific zones to protect future public water-supply installations, (3) withdrawal of water supplies from wells in the deeper part of the Magothy(?) formation, particularly where population and industry are relatively dense, and (4) construction of sanitary sewer systems in present and potential areas of high population density. 


\section{INTRODUCTION}

\section{SCOPE AND PURPOSE OF INVESTIGATION}

The present report on the ground-water resources and related geologic environment of the Huntington-Smithtown area is part of an overall program for the continung appraisal of the ground-water reservoir on Long Island. This program, begun in 1932, has been carried on by the U.S. Geological Survey in cooperation with the New York State Water Resources Commission (formerly New York State Water Power and Control Commission), the Nassau County Department of Public Works, the Suffolk County Water Authority, and the Suffolk County Board of Supervisors. Fieldwork on the present investigation was started by the author during November 1957 and continued through May 1959.

The purpose of the work was as follows: To determine the thickness and areal extent of water-bearing formations, to define the nature and direction of ground-water movement, to evaluate the hydraulic properties of the water-bearing materials, to determine replenishment and withdrawals for appraising the optimum location of potential centers of withdrawal from the ground-water reservoir, and to appraise the chemical character of the ground water with respect to its general use and to sea-water encroachment and contamination by domestic and industrial wastes.

\section{LOCATION AND FXTENT OF AREA}

The area of investigation comprises the Town of Huntington and the adjacent Town of Smithtown in northwestern Suffolk County, Long Island, N.Y. (fig. 1). The Town of Huntington (also called Huntington in this report) makes up the western part of the project area, and the Town of Smithtown (also called Smithtown in this report) makes up the eastern part. Both towns have villages bearing the same name. Where the village is referred to, the full name is given-for example, village of Huntington.

The east-west length of the project area is about 20 miles, and the north-south width ranges from 7 to 12 miles. The land area is approximately 153 square miles. It is bordered on the north by Long Island Sound, on the west by Nassau County, on the east by the Town of Brookhaven, and on the south by the Towns of Babylon and Islip. The western limit is about 30 miles east of Manhattan (New York County), New York City.

\section{PREVIOUS INVESTIGATIONS}

Many ground-water and geologic studies, mostly of small scope have been made of Long Island, but the earliest and most compre- 


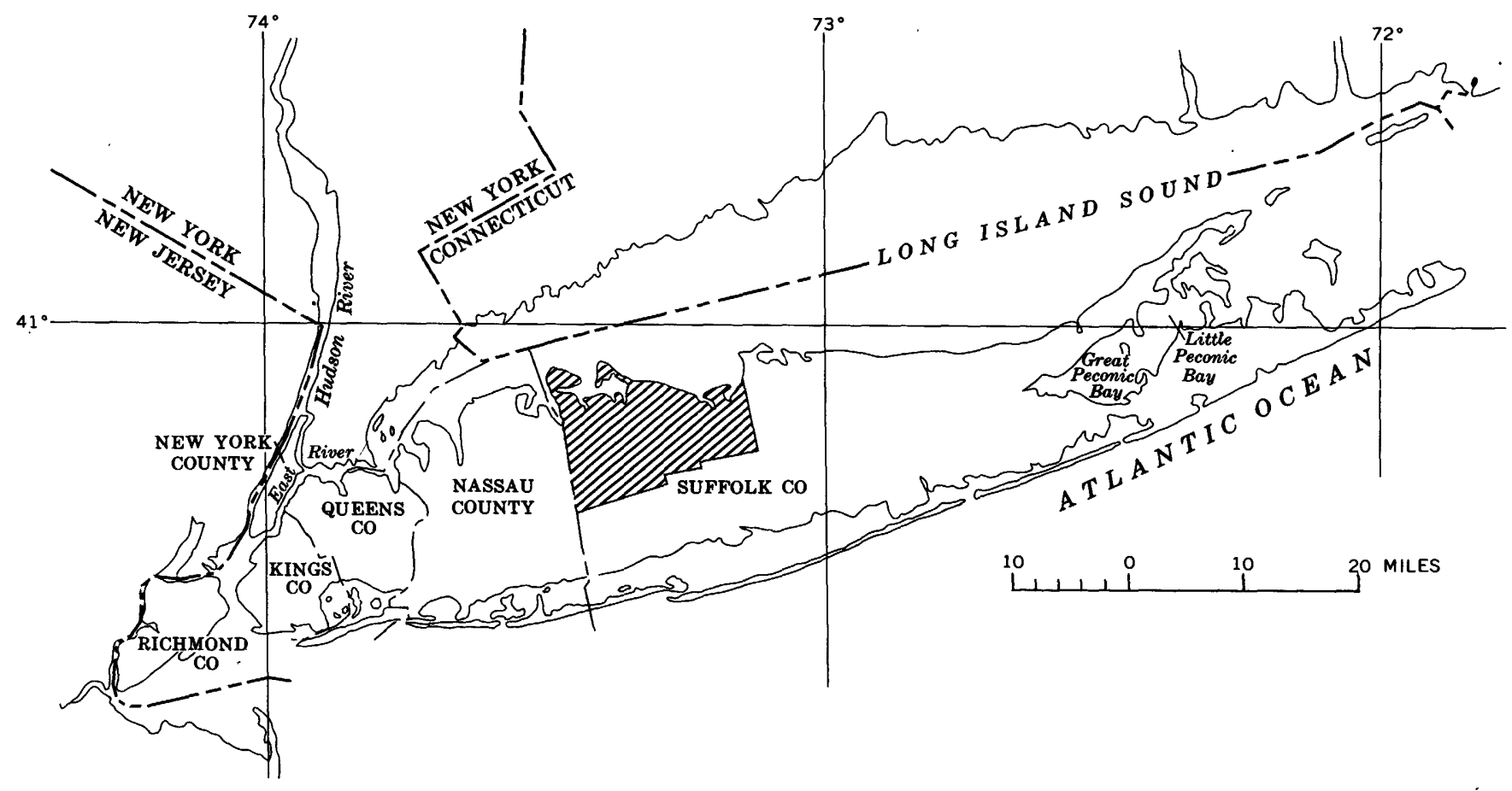


hensive areal ground-water investigation was made by Veatch and others(1906). Subsequent studies, primarily geologic, were made by Fuller (1914) and by Suter, de Laguna, and PerImutter (1949). Horace R. Blank (written communication, 1928) studied the groundwater and geology of the Smithtown area. The New York State Water Resources Commission in cooperation with the U.S. Geological Survey has published three bulletins, GW-4 (U.S. Geol. Survey, 1938), GW-9 (Roberts and Brashears, 1945), and GW-31 (New York State Water Power Control Comm., 1952), in which well logs and related hydrologic data have been compiled for Suffolk County. Additional contributions to the geology have been made by other investigators, including Thompson, Wells, and Blank (1937) and Fleming (1935). The surficial geology of the Huntington-Smithtown area was originally mapped by Fuller (1914), whose interpretation was similar to the one given in this report. More recently, Wiggin (1957) evaluated the need for the development and distribution of the available water supply of Suffolk County, Long Island. In his conclusions, Wiggin pointed up the need for more specific analysis and interpretation of the geology and hydrology of Suffolk County, particularly with reference to the future development and use of the county's water resources.

\section{ACKNOWLEDGMENTS}

The assistance of many individuals and agencies has greatly facilitated the progress of this investigation. The author wishes to express his thanks for the help given by numerous well drillers and public and private water-supply officials. The New York State Water Resources Commission, the Suffolk County Water Authority, and Suffolk County officials supplied essential basic information. The officials of the Northport Veterans Hospital and the Kings Park State Hospital also were very cooperative in supplying hydrologic data. Many private individuals generously gave permission to use their wells for observation. The report was prepared under the supervision of G. C. Taylor, Jr., formerly District Geologist, and N. M. Perlmutter, geologist-in-charge, Mineola subdistrict office.

\section{WELL-NUMBERING SYSTEM}

Wells drilled in Long Island are assigned serial numbers by the New York State Water Resources Commission, Westbury, N.Y., and logs and related hydrologic data for these wells are retained by the same agency. Well numbers are prefixed by a capital letter designating the county in which they are located. For example, $\mathrm{S}$ indicates wells in Suffolk County; N, wells in Nassau County. For 
convenience in this report, however, the prefixes have been omitted from the number of wells plotted on plates 1 and 5 . The map coordinates by which individual wells may be approximately located in plate 1 are given in table 7. Geologic and hydrologic data for wells shown on plate 1 but not published in this report are available for consultation in the files of the Geologic Survey office at Mineola, N.Y., and the New York State Water Resources Commission at Westbury, N.Y.

\section{GEOGRAPHY}

\section{PHYSIOGRAPHY AND DRAINAGE}

The Huntington-Smithtown area is in north-central Long Island, which is the partly submerged northeastern extension of the Atlantic Coastal Plain. The physiographic features, which are largely of glacial origin, may be grouped into five morphologic units from north to south: (1) the headlands and bays along the margin of Long Island Sound; (2) the Harbor Hill end moraine, (3) an intermorainal belt, (4) the Ronkonkoma terminal moraine with contiguous clusters of hills, and (5) a southward-sloping glacial outwash plain.

Two prominent headlands, Lloyd Neck and Eatons Neck, tied by low sand and gravel bars to the mainland, rise abruptly from Long Island Sound to uniform altitudes of about 100 feet. Between these headlands lies Huntington Bay, whose shoreline is broken by several smaller indentations including Lloyd, Huntington, Centerport, Northport and Duck Island Harbors, and Northport Bay. East of Lloyd Neck is Cold. Spring Harbor, and north of Smithtown is the broad indentation of Smithtown Bay, whose shoreline is notched by the Nissequogue River estuary and Stony Brook Harbor. Lying south of the headlands and the heads of the bays and harbors is the irregular, discontinuous ridge of the Harbor Hill end moraine, which trends east-northeast across the entire area. This ridge reaches summit altitudes generally ranging from 250 to 300 feet and is breached in several places by the valleys of streams draining north to Long Island Sound. South of the Harbor Hill terminal moraine is an intermorainal belt lying at altitudes of between 160 and 200 feet; the belt is about 1 to 4 miles wide and is slightly dissected by shallow north-flowing streams. The broad valley of the Nissequogue River, the largest stream in the project area, is in this belt.

The Ronkonkoma terminal moraine also forms an irregular ridge lying to the south of the intermorainal belt and trending west across Huntington and through southwestern Smithtown. The summit altitudes on this ridge range from about 340 to 380 feet, and the ridge is breached in three places by broad-floored gaps at altitudes of 140 to 160 feet marking the former spillways of south-flowing 
glacial melt water streams. In central and southern Huntington the east-west alinement of the ridge is broken by the West and Half Hollow Hills, which extend south to the town boundary. South of the Ronkonkoma moraine and the contiguous hills and abutting these on the north at altitudes of about 80 to 100 feet is an outwash plain, which slopes uniformly south at about 20 feet to the mile to the Atlantic Ocean.

Several streams, discharging into Long Island Sound, flow through the area and generally lie in north-trending valleys. The Nissequogue River is the largest stream, and its drainage basin, which is almost entirely in Smithtown, includes about 26 square miles. This stream ends in a relatively large estuary, which extends 2 to 3 miles inland. Other smaller streams are Mill Creek, Stony Hollow Run, Sunken Meadow Creek, and Cold Spring Brook draining a part of Nassau County. Most of these streams are in the town of Huntington. The southeast corner of Smithtown borders on Lake Ronkonkoma, the largest natural lake on Long Island. This lake originated as a glacial kettle; its bottom intersects the water table and normally does not overflow.

\section{CULTURE}

Since World War II the population and industry of the entire Huntington-Smithtown area have grown rapidly, but the growth has been most pronounced in Huntington (fig 2). The population in 1958 for the project area was estimated to be 153,000 , based on a survey made by the Long Island Lighting Co. A continuing growth in population is indicated by the present (1960) construction of new homes through much of the area. Concurrent with the population increase is the growth of light industries, most of which make electronic equipment.

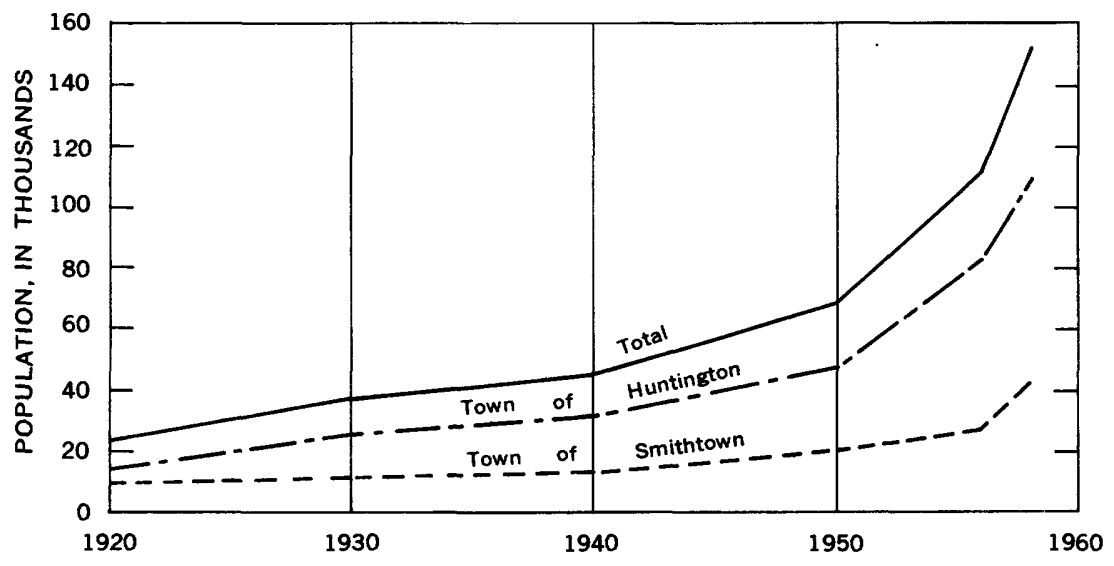

FrgdRz 2.-Population trends in the Huntington-smithtown area. 
Agriculture is still practiced, but the large-scale construction of private dwellings has made marked inroads into the total farmed acreage. The decrease in farmed acreage is well demonstrated in Smithtown, where more than 4,000 acres devoted to agriculture in 1945 were reduced to about 1,800 acres in 1958. As elsewhere in central and eastern Long Island potatoes are the major agricultural crop. In addition, garden vegetables, cauliflower, wheat, and rye are also grown extensively for local and national markets.

\section{CLIMATE}

The climate of the Huntington-Smithtown area is relatively mild with extremes of temperature moderated considerably by the ocean. The average annual temperature is about $52^{\circ} \mathrm{F}$. The average minimum and maximum monthly temperature of $31^{\circ} \mathrm{F}$ and $73^{\circ} \mathrm{F}$ occur during January and July, respectively. The average annual precipitation is about 49 inches, and is distributed relatively evenly throughout the year. A minimum and maximum annual precipitation of 36.4 inches (1957) and 69.2 inches (1898), have been recorded at the rain-gaging station in Brentwood, about 9 miles southwest of the village of Smithtown. The minimum monthly precipitation occurs generally in June and the maximum in August.

Precipitation and temperature data are available for six stations in the Huntington-Smithtown area and its immediate vicinity. Precipitation data for these stations are summarized in table 1 . The length of record available for each station ranges from 7 to 31 years. Records of precipitation in Brentwood were maintained from 1891 to 1900 and then continuously since 1941 . The average annual precipitation recorded for each station listed in table 1 ranges from 45.9 inches at Farmingdale, about 11 miles southwest of Huntington, to 56.2 inches at Lake Ronkonkoma. In the project area a minimum monthly rainfall of less than 0.01 inch has been observed during June, and a maximun of 14.4 inches during October.

TABLE 1.-Summary of average monthly and annual precipitation at stations in or adjacent to the Huntington-Smithtown area

\begin{tabular}{|c|c|c|c|c|c|c|c|c|c|c|c|c|c|c|}
\hline \multirow{2}{*}{ Station } & \multirow{2}{*}{$\begin{array}{l}\text { Period of } \\
\text { record }\end{array}$} & \multicolumn{12}{|c|}{ Average monthly precipitation } & \multirow{2}{*}{$\begin{array}{c}\text { Aver- } \\
\text { age } \\
\text { annual } \\
\text { precip- } \\
\text { itation }\end{array}$} \\
\hline & & Jan. & Feb. & Mar. & Apr. & May & June & July & Aug. & Sept. & Oct. & Nov. & Dec. & \\
\hline $\begin{array}{l}\text { Babylon } \\
\text { Brentwood. }\end{array}$ & $\begin{array}{l}1938-58 \\
1891-1900\end{array}$ & $\begin{array}{l}4.01 \\
4.10\end{array}$ & $\begin{array}{l}3.73 \\
3.41\end{array}$ & $\begin{array}{l}5.00 \\
4.48\end{array}$ & $\begin{array}{l}3.84 \\
3.72\end{array}$ & $\begin{array}{l}3.91 \\
4.21\end{array}$ & $\begin{array}{l}3.52 \\
2.62\end{array}$ & $\begin{array}{l}3.78 \\
4.22\end{array}$ & $\begin{array}{l}5.72 \\
4.91\end{array}$ & $\begin{array}{l}3.08 \\
2.73\end{array}$ & $\begin{array}{l}3.50 \\
3.64\end{array}$ & $\begin{array}{l}4.84 \\
4.84\end{array}$ & $\begin{array}{l}3.84 \\
3.91\end{array}$ & $\begin{array}{l}48.77 \\
48.79\end{array}$ \\
\hline Farmingdale_. & $1921-34$ & 3.17 & 3.18 & 4.15 & 3.78 & 3.98 & 3.86 & 3.86 & 5.18 & 3.36 & 3. 58 & 4.25 & 3.56 & 45.91 \\
\hline Huntington & 195 & 3.11 & 3.47 & 4.88 & 4.23 & 3.77 & 1. 46 & 2.84 & 5.99 & 3.00 & 4.80 & 4.53 & 4.06 & 47.04 \\
\hline $\begin{array}{l}\text { Lake } \\
\text { Ronkonko }\end{array}$ & $1948-58$ & 5. 05 & 4.53 & 5.86 & 4.79 & 5.35 & 2.99 & 3.43 & 5.56 & 3.41 & 4.44 & 5.17 & 5.66 & 56.24 \\
\hline St. James & $1953-5$ & 2.86 & 3.27 & 4.86 & 4. 27 & 3.35 & 2.02 & 2.98 & 5.32 & 3.84 & 5.09 & 4.76 & 4.16 & 46.88 \\
\hline
\end{tabular}


HYDROGEOLOGY OF HUNTINGTON-SMITHTOWN AREA, N.Y. D9

\section{GEOLOGIC FORMATIONS AND THEIR WATER-BEARING CHARACTER}

\section{GENERAI FEATURES}

The Huntington-Smithtown area is underlain by 400 to 1,300 feet of unconsolidated deposits of Cretaceous, Tertiary (?), and Quaternary age resting upon a surface of southeast-sloping bedrock. The bedrock is probably of igneous and metamorphic origin and of Precambrian to early Paleozoic age, as in other parts of Long Island. Deposits of Late Cretaceous age rest unconformably upon the bedrock surface. A summary of the stratigraphic sequence in the Huntington-Smithtown area is given in table 2.

The Raritan formation of Late Cretaceous age is the oldest unconsolidated deposit. This formation is divided into a basal Lloyd sand member and an upper clay member, which is generally overlain by the Magothy(?) formation, also of Late Cretaceous age. Pliocene(?) deposits (Suter and others, 1949, footnote p. 9) are represented by the Mannetto gravel, remnants of which lie on the Magothy (?) formation chiefly in the Mannetto Hills of eastern Nassau County and in the West Hills of the Town of Huntington.

Deposits of Pleistocene age belonging to one or more glacial stages and one interglacial stage have been recognized in Long Island, but not all these have been identified in the HuntingtonSmithtown area. The Jameco gravel, an early glacial-outwash deposit of pre-Wisconsin age, is widely distributed in western Long Island where it is recognized entirely in well logs (Suter and others, 1949, pl. 20). It may also be present in some of the deeper buried valleys of the Huntington-Smithtown area but has not been positively identified. An interglacial shallow marine deposit, the Gardiners clay, has been recognized in western and central Long Island. (See Suter and others, 1949, pls. 17 and 21, and Weiss, 1954.) This formation, also of pre-Wisconsin age, was deposited around the margins of Long Island when sea level was about 50 feet lower than it is now. The Gardiners or its nonmarine equivalent may be present in some deep buried valleys of the project area, but it has not been recognized separately in well logs because of its lithologic similarity to younger clay of probable glaciolacustrine origin. Glacial deposits of the Wisconsin stage, also termed upper Pleistocene deposits in this report, constitute the bulk of the Pleistocene sequence. These deposits generally rest directly on the deposits of Cretaceous age and locally on the Mannetto gravel of Pliocene(?) age or on undifferentiated deposits of Pleistocene age. 
The glacial origin of the surficial Pleistocene deposits is indicated by two morainal ridges, which traverse the length of the project area (pl.2). The Ronkonkoma terminal moraine in the south marks the maximum advance and its northern counterpart, the Harbor Hill end moraine, mark a second position of an ice sheet, which covered much of Long Island during the Wisconsin glacial stage. In the Huntington-Smithtown area the stratification and morphology of the deposits in these ridges indicate that they are chiefly coalescing kame-type structures formed along a relatively stationary ice front. In Huntington the Ronkonkoma moraine lies on the northern fringe of the West Hills and rests on the Mannetto gravel. A surficial till sheet attaining a thickness generally no greater than about 10 feet is common on upland surfaces of the project area north of the Harbor Hill moraine. Surficial deposits of sand and gravel, laid down by melt-water streams issuing from the ice front, form a pitted outwash plain in the intermorainal belt between the ridges formed by the Harbor Hill and Ronkonkoma moraines and a relatively smooth south-sloping outwash plain south of the Ronkonkoma moraine.

Deposits of Recent age are thin and are limited chiefly to shoreline areas.

\section{BEDROCK}

The lower limit of the ground-water reservoir in the HuntingtonSmithtown area is marked by an erosional surface on a complex of igneous and metamorphic rocks, which are of Precambrian and possibly early Paleozoic age. The bedrock underlying Long Island is composed chiefly of granite, diorite, gneiss, and schist.

Evidence of the nature of the bedrock in the Huntington-Smithtown area is available only from two wells, S34 (U.S. Geol. Survey, 1938, p. 25) and N3355 (pl. 4). Well S34 (pl. 4) on Duck Island southeast of Eatons Neck is reported to have penetrated bedrock at 602 feet below land surface $(597 \mathrm{ft}$ below sea level). The driller's report described the bedrock as a "sandstone." If this description is correct, this occurrence would be the only sandstone bedrock recorded in Long Island. It is likely however, that the driller's description is in error and that the material described as "sandstone" is actually weathered igneous or metamorphic rock. Weathered bedrock, 1,218 feet below the land surface $(1,035 \mathrm{ft}$ below sea level), also was penetrated in well N3355 situated in Nassau County near the western limit of the project area. The general composition of the weathered material at this site suggests igneous and metamorphic parent rocks, which are common in other parts of Long Island.

The weathered zone above the fresh rock is regarded as lateritic and probably formed immediately prior to the deposition of the Cre- 
taceous sediments. The weathered zone is generally composed of variegated clay containing partly decomposed fragments of bedrock. It ranges in thickness from 5 to 100 feet (Suter and others, 1949, p. 13).

The bedrock surface, striking east-northeast, is a relatively smooth plane which slopes at about 80 feet per mile southeastward across the Huntington-Smithtown area (Suter and others, 1949, pl. 8). This surface ranges from about 400 feet below sea level in the northwestern part of the project area to about 1,300 feet below sea level in the vicinity of Lake Ronkonkoma. Owing to the low permeability, the water-yielding potential of the bedrock is poor in comparison with that of the overlying unconsolidated deposits. Consequently, the bedrock is not considered to be a source of ground water.

\section{UPPER CRETACEOUS SERIES}

In the Huntington-Smithtown area, as elsewhere on Long Ișland, deposits of Late Cretaceous age are divided into two formations, the Raritan formation and the overlying Magothy(?) formation, which is in part equivalent to the Magothy formation of New Jersey. This sequence of deposits is composed of interbedded layers of sand, gravel, silt, and clay that dip gently to the southeast subparallel to the slope of the underlying bedrock surface. The Raritan and Magothy (?) formations were probably deposited largely by sluggish streams in a low swampy coastal-plain environment. However, marine facies may be present, at least locally, in these deposits, if one report of fossils is correct. According to Veatch and Bowman (1906, p. 297), a crinoid stem and a bryozoan were found in samples taken from a depth of 247 feet in well S230 (pl. 4). These marine fossils in the Lloyd sand member of the Raritan formation are considered to be of Late Cretaceous age. Marine beds, possibly correlative with the Monmouth Group, also have been identified in the upper part of the Magothy (?) formation in southwestern Suffolk County (Perlmutter and Crandell, 1959, p. 1066). The Cretaceous deposits generally increase in thickness southeastward. The deposits, however, were deeply dissected by stream erosion during Tertiary and probably early Pleistocene time and the resulting erosional surface on the Cretaceous in the project area has relief which in places exceeds 500 feet (pl. 3). This surface was subsequently buried by Pleistocene glacial and marine deposits, although the Cretaceous is covered by younger deposits in virtually the entire project area, small outcrops occur near sea level in bluffis and along the beaches on the north shore of Lloyd Neck, on the west side of Eatons Neck, and on the east side of Cold Spring Harbor (pl. 3). One small 
outcrop also was observed in an excavation in the West Hills at an altitude of 250 feet (pl. 3). The geologic relations of the Cretaceous and younger deposits are shown in plate 4 .

\section{RARITAN FORMATION}

The Raritan formation probably is present throughout the Huntington-Smithtown area according to available well logs. The upper surface of the Raritan, which also is the upper surface of the clay member, slopes southeastward. It has considerable relief in the northern part of the area. This relief is the result of post-Cretaceous erosion. The upper surface of the clay member is about 100 feet below sea level in the northwestern part of Lloyd Neck (pl. 4) and is about 700 feet below sea level in the vicinity of Lake Ronkonkoma (pl. 4). In the same localities the top of the Lloyd sand member ranges from 200 to 850 feet below sea level. Approximate contours on the surface of the Lloyd sand member and of the clay member are given in Suter and others (1949, pls. 11, 12, 14, and 15). Depths to the top of these surfaces also are shown in the geologic sections (pl. 4).

The Lloyd sand member rests unconformably on bedrock in most of the area, and has been penetrated completely by test well N3355 (pl. 4), which is in Nassau County just west of the project area. At this site the total thickness of the Lloyd is 265 feet. In the Huntington-Smithtown area the Lloyd presumably is penetrated entirely by well S34, but no $\log$ is available. Several other wells (S9, S217, S230, and S4467, pl. 4) have been drilled 50 to 120 feet into the Lloyd. The logs of these wells suggest that the Lloyd consists chiefly of lenses of fine to coarse sand and gravel but that it contains clay and silt as thin layers or as intergranular fillings. The color of the Lloyd sand member is generally white and gray, but in a few places it is pale yellow.

The clay member of the Raritan, which overlies the Lloyd sand member, is composed chiefly of beds of variegated clay and silt, which contain interbedded layers of sand in some places. Lignite in dispersed fragmental form ànd iron oxide and pyrite nodules are also common. The clay member ranges in thickness from 0 to 188 feet and averages about 170 feet. In general, well logs indicate that the thickness and physical character of the clay member are relatively uniform throughout the Huntington-Smithtown area (pl. 4).

The clay member of the Raritan generally consists of material of relatively low permeability and acts as an aquiclude, which confines water in the underlying Lloyd and retards interchange of water with the overlying Magothy (?) formation. 
The Lloyd sand member is a significant source of water in Queens and Nassau Counties, where wells may yield as much as 1,600 gpm (gallons per minute). The Lloyd has not been developed extensively in Suffolk County. Several domestic and public-supply wells are screened in the Lloyd in the northern part of the Town of Huntington. The record of a typical well tapping the Lloyd is given in table 1. Because of the lack of data, it is not possible to estimate directly the hydraulic properties of the Lloyd sand member in the Huntington-Smithtown area. Swarzenski (1961, p. 27), however, has made estimates indicating that the coefficient of permeability (Wenzel and Fishel, 1942, p. 7) of the water-bearing zones in the Lloyd sand member in northwestern Nassau County may range from 200 to $600 \mathrm{gpd}$ (gallons per day) per sq ft. Comparable coefficients of permeability also may be expected in the project area. In 1957, pumpage from the Lloyd sand member accounted for only about 3 percent of the total pumpage for public supply and industrial use in the Huntington-Smithtown area.

\section{MAGOTHY(?) FORMATION}

The Magothy (?) formation rests on the top of the Raritan formation and underlies most of the Huntington-Smithtown area. The upper limit of the Magothy (?) is marked by a highly irregular erosional surface (pl. 3), upon which rest deposits of Pleistocene and in some places Pliocene(?) age. The maximum relief on this surface is greater than 500 feet. This surface on the Magothy(?) formation has a maximum known altitude of about 250 feet in the West Hills area, but in several areas it lies 200 feet or more below sea level. The Magothy (?) formation is as much as 800 feet below sea level near the southern limit of the Huntington-Smithtown area, but data from well logs and samples suggest that in several places the formation is missing, as for example, in the Huntington buried valley (pl. 4).

The upper part of the Magothy (?) formation is composed mostly of layers of fine to medium quartz sand, generally somewhat clayey and interbedded with layers of clay and silt. (See the following well logs.) Gravelly layers, which occur in a few places, appear to be lenticular and have relatively small areal extent. Colors range through white, gray, brown, yellow, and red, but the sandy layers generally have a somewhat lighter color owing to the presence of intergranular fillings of white clay. Lignite in fragmental form and pyrite and iron oxide nodules are commonly dispersed throughout the formation. 


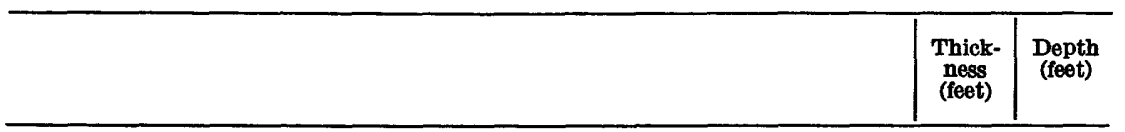

S15899-T. (10E)

[Suffolk County Water Authority, Carlson Ave., Kings Park, N.Y. Drilled in 1957 by C. W. Lauman and Co., Inc. Test well. Alt $170 \mathrm{ft}$. Log based on examination of core samples]

Recent deposits:

Loam

Upper Pleistocene deposits:

Sand, coarse, and gravel; brown

Sand, coarse, gravel, and cobbles; brown

Sand, coarse, gravel, boulders, and clay lumps; brown

Sand, coarse, gravel, and boulders; brown

Sand, coarse, cobbles, and clay lumps; brown

Sand, coarse, coarse gravel, and clay layers; brown Magothy(?) formation:

Sand, fine to medium, light-brown and gray; contains some thin layers of white clay .......

Silt, clayey, white-gray, micaceous brown

Clay, buff

Clay, gray; some lignite

Clay, silty, light-gray and light-brown

Sand, fine to medium, clayey, light-gray and yellowish-brown, micaceous

Sand, fine to coarse, yellowish-brown, micaceous; scattered layers of gray clay.

Sand, very fine, clayey, whitish-gray

Sand, fine to medium, light-brown

Sand, medium to very coarse, yellowish-brown

Sand and clayey silt, light-brown; few layers of clay

Sand, fine to medium, and some gravel; light brown

Sand, fine to coarse, gravelly, and some clay; light brown...

Sand, medium to coarse, and some gravel; few clay layers; light brown . . . . . . . .

Sand, medium to coarse, gravelly, light brown

Sand, fine to coarse, clayey, light-gray

Sand; medium to coarse, and gravel; light-brown

Sand, medium to coarse, light brown.

Sand, fine to coarse, graveliy and clayey, light-brown ......

Sand, fine to medium, clayey, light-gray; some limonitic concretions . . . . . . .

Sand, medium to coarse, clayey, and some gravel; light-brown

and light-gray

Sand, fine, clayey, whitish-brown; few layers of clay Raritan formation:

Sand, fine to coarse and gravel, clayey

Clay member:

Sand, very fine, clayey, light-gray, micaceous
Sand, fine, clayey, light-gray, reddish-brown, and yel-

lowish-brown

Silt, clayey, light-gray.

\begin{tabular}{r|r} 
& \\
2 & 2 \\
60 & 62 \\
66 & 128 \\
12 & 140 \\
8 & 148 \\
20 & 168 \\
11 & 179 \\
& \\
141 & 320 \\
5 & 325 \\
29 & 354 \\
11 & 365 \\
15 & 380 \\
9 & 389 \\
7 & 396 \\
56 & 452 \\
3 & 455 \\
14 & 469 \\
6 & 475 \\
13 & 488 \\
6 & 494 \\
25 & 519 \\
20 & 539 \\
77 & 546 \\
16 & 562 \\
3 & 565 \\
15 & 580 \\
13 & 593 \\
7 & 600 \\
11 & 611 \\
15 & 626 \\
10 & 636 \\
18 & 654 \\
& \\
39 & 693 \\
7 & 700 \\
6 & 706 \\
& \\
\hline
\end{tabular}




\begin{tabular}{c|c}
$\begin{array}{c}\text { Thick- } \\
\text { ness } \\
\text { (feet) }\end{array}$ & $\begin{array}{c}\text { Depth } \\
\text { (feet) }\end{array}$
\end{tabular}

S15923. (10E)

[Indian Head Water Co., Indian Head Rd., Indien Head, N.广். Drilled in 1958 by C. W. Lauman and Co., Inc. Casing diameter 16 in., screen settings from 148 to $165 \mathrm{ft}, 189$ to $229 \mathrm{ft}$, and 253 to $263 \mathrm{ft}$. Alt $130 \mathrm{ft}$. Log based on examination of core samples]

Recent deposits:

Top soil and loam

Upper Pleistocene deposits:

Sand, coarse, and gravel; brown

Sand, coarse, and gravel; some clay; brown

Sand, coarse, and gravel; brown.

Sand, fine, brown

Sand, coarse to very coarse, gravelly, yellowish-brown Magothy(?) formation:

Sand, fine to coarse, light-brown; some lumps of white clay -.

Sand, very fine to medium, clayey; white......

Clay interbedded with fine sand and silt; laminar bedding - -

Sand, very fine to fine, whitish-gray

Sand, medium, yellowish-brown

Sand, medium to coarse, light-brown

Sand, medium to coarse, light-brown; some clay -

Sand, medium to coarse, buff.

Clay interbedded with silt, buff, grayish-brown; laminar

bedding . . . . . . .

Clay, dark-gray laminated, lignitic

Sand, fine to medium, clayey, whitish-brown

Sand, fine to medium, buff.

Sand, medium to coarse, buff and red; some white clay.

Sand, fine to medium .

Sand, medium, light-gray and reddish-brown; few fragments of cemented red sandstone. . . . . .

Sand, medium, reddish-brown

Sand, medium, reddish-brown; some layers of clay

Sand, fine to medium, buff; some lignite and few limonitic concretions . -

Sand, fine to medium, buff and light-gray; some clay lumps. -

Sand, very fine, clayey, whitish-gray - very fine to medium, clayey, whitish-gray and buff.-

Clay, silty, light-gray . .

Sand, very fine, clayey, whitish-brown-

Sand, fine to medium, clayey, whitish-gray and buff; some limonitic concretions.

Sand, fine, clayey, buff; some white clay layers

-Sand, fine, whitish-gray; interbedded with clay and silt;

laminar bedding with clayey silt

Sand, fine to medium, clayey, whitish-brown

Sand, fine, clayey, whitish-brown

Sand, fine to medium, clayey, light-brown

Sand, fine, clayey, whitish-brown.

Silt interbedded with very fine sand and lignite, gray; some concretions of pyrite

Sand, fine to medium, clayey, whitish-brown

Sand, very fine to medium, clayey, buff, whitish-gray . ......

Silt, clayey, whitish-gray; some lignite.

Clay, brown and gray

Clay, silty, gray; some lignite.

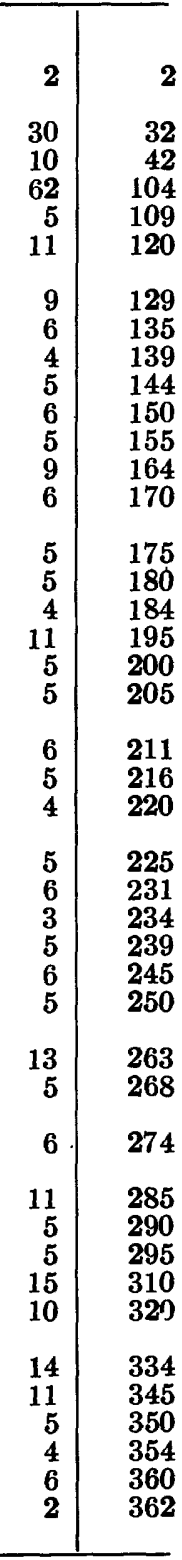


TABLE 2.-Summary of the stratigraphy and water-bearing properties of the deposits underlying the Huntington-Smithtown area, Suffolk County, N.Y.

\begin{tabular}{|c|c|c|c|c|}
\hline System & Beries & Stratigraphic unit & $\begin{array}{c}\text { Thickness } \\
\text { (feet) }\end{array}$ & Character of deposits \\
\hline \multirow{3}{*}{ 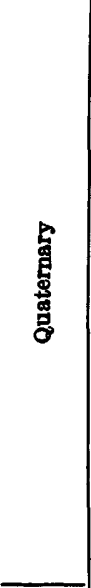 } & $\stackrel{\rightleftarrows}{8}$ & $\begin{array}{l}\text { Recent deposits Artificial } \\
\text { fll, marsh deposits, } \\
\text { beach deposits, and sur- } \\
\text { ficial soll. }\end{array}$ & $0-20 \pm$ & $\begin{array}{l}\text { Sand, gravel, silt, and clay; organic mud, peat, loam, and } \\
\text { shells. Colors are brown, yellow and gray. }\end{array}$ \\
\hline & \multirow[t]{2}{*}{ 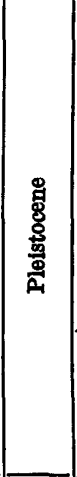 } & $\begin{array}{l}\text { Upper Pleistocene } \\
\text { deposits. }\end{array}$ & $0-300 \pm$ & $\begin{array}{l}\text { Till composed of unassorted clay, sand, and boulders as } \\
\text { ground moraine in area north of Harbor Hill terminal } \\
\text { moraine and possibly as buried ground mpraine of the } \\
\text { Ronkonkoma ice. } \\
\text { Outwash deposits of brown well-stratified sand and } \\
\text { gravel-predominantly quartzose but containing biotite } \\
\text { and other dark minerals and igneous and metamorphic } \\
\text { rock fragments-including advance outwash, channel } \\
\text { and valley-fill, and outwash-plain deposits. } \\
\text { Ice-contact deposits of crudely stratified sand and gravel } \\
\text { and isolated masses of till in the Ronkonkoma and } \\
\text { Harbor Hill terminal moraines. } \\
\text { Glaciolacustrine deposits of brown and gray silt and clay } \\
\text { intercalated with outwash deposits in buried valleys. }\end{array}$ \\
\hline & & $\begin{array}{l}\text { Pleistocene deposits un- } \\
\text { differentiated. }\end{array}$ & $0-400 \pm$ & $\begin{array}{l}\text { Sand, gravel, clay, and silt. Lignite present in some silt } \\
\text { or clay layers. Colors are brown and gray. These de- } \\
\text { posits are present in deep buried valleys and may in- } \\
\text { clude equivalents of the Gardiners clay and the Jameco } \\
\text { gravel found elsewhere on Long Island. This unit may } \\
\text { include some Pliocene(?) deposits, but evidence is scanty. }\end{array}$ \\
\hline \multirow[t]{2}{*}{ 密 } & ङ & \multirow{2}{*}{$\begin{array}{l}\text { Mannetto gravel } \\
--- \text { Unconformity - }\end{array}$} & $0-300 \pm$ & $\begin{array}{l}\text { Stratifled sand and gravel and scattered clay lenses; unit } \\
\text { is predominantly quartzose; igneous and metamorphic } \\
\text { rock fragments are scarce. Colors are pale to yellowish } \\
\text { brown. Caps hills in western part of Huntington and } \\
\text { locally present in buried valleys. }\end{array}$ \\
\hline & & & $0-800 \pm$ & $\begin{array}{l}\text { Sand, clayey, with silt, clay, and some gravel. Colors are } \\
\text { white, gray, brown, yellow, and red. The upper part } \\
\text { of the formation commonly includes interbedded clay, } \\
\text { fine to medium sand, silt, and some lignite; the lower } \\
\text { part is largely coarse sand, gravel, and some clay. }\end{array}$ \\
\hline
\end{tabular}

Water-bearing properties

Sandy and gravelly beach deposits may locally yield small supplies of fresh to brackish water to wells. Marine silt and clay in north-shore harbors retard salt-water encroachment and confine underlying aquifers.

Till, relatively inpermeable; commonly causes perchedwater bodies to form locally and impedes recharge from

Outwash and ice-contact deposits are moderately to highly permeable. Wells screened in outwash deposits gen-

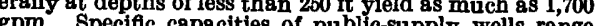
from 22 to 222 com erally fresh and unconfined. Chief source of water for domestic, public-supply, industrial, and irrigation wells in project area.

Glaciolacustrine deposits of silt and clay are relatively impermeable and locally retard movement of water between adjacent water-bearing beds in Pleistocene and Cretaceous deposits.

Coarser sand and gravel beds are permesble and would presumably yield moderate to large supplies to properly deposits yields $1,400 \mathrm{cpm}$, 46 gpm yer ft of drawdown. Silt and cla beds confln water in adjacent water-bearing beds.

Deposits are moderately to highly peremeable but generally lie above the znne of saturation. Locally, water supplies for domestic use are obtained from these deposits, such as at wells S4, S208 and S827. No large public-supply or industrial wells were screened in these deposits in 1960.

Generally ranges from moderately to highly permeable. The lower part of the formation is more permeable than the bel zone he plelds rano-supply 1,000 to 1,500 in and specific capacities from 30 to $90 \mathrm{gpm}$ per ft of draw down. Water is generally of excellent quality. Second 


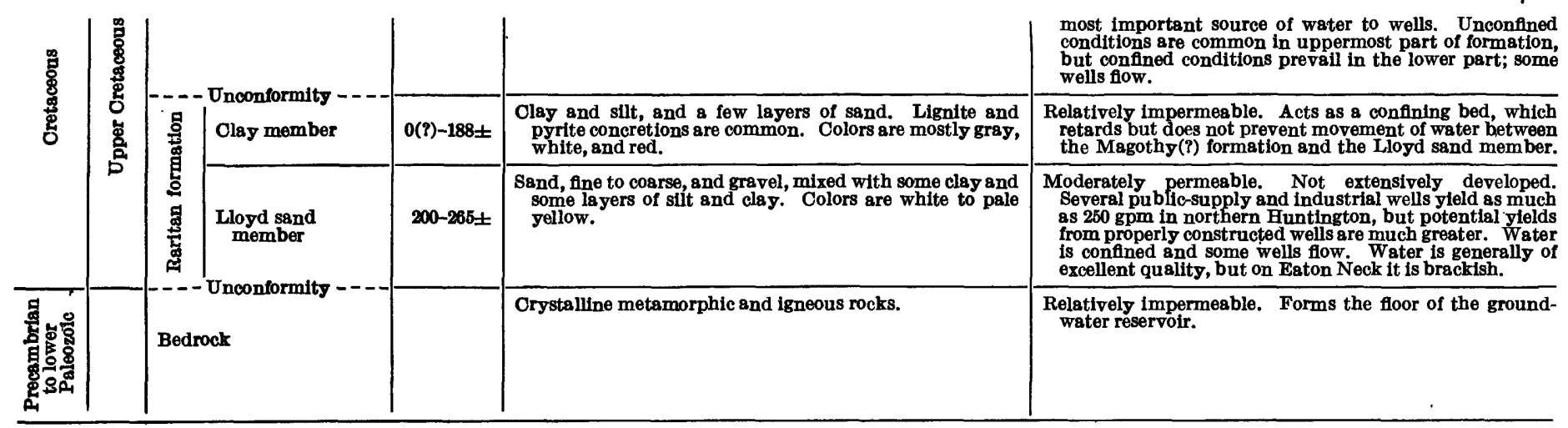


The lower part of the Magothy (?) formation becomes increasingly coarser textured at depth, as indicated by the greater frequency of gravelly layers. Several wells, which have penetrated the basal zone of the Magothy(?), have penetrated thick layers of gravel intercalated with layers of finer grained sediments (pl. 4). This gravelly zone, which appears to be present through most of the project area, rests directly on the clay member of the Raritan. It crops out in bluffs along the northwest coast of Lloyd Neck (pl. 2). The upper limit of the gravelly zone is poorly defined but is presumably gradational into finer grained sediments characteristic of the upper part of the Magothy (?). The maximum thickness of this zone is about 200 feet.

Most of the wells in the project area that penetrate Cretaceous deposits are screened in the upper part of the Magothy(?) formation, where the preponderance of fine-grained materials limits the water-yielding capacity of the wells. Locally, there are more productive water-bearing zones, but these are generally of small vertical and lateral extent. . The basal part of the Magothy (?) is the most productive water-yielding zone of the formation. Although relatively few wells were screened in this zone in 1960, test-well data indicate conditions favorable for development to meet future water demands. The Magothy (?) formation is the second most important source of water tapped by industrial and public-supply wells in the project area-particularly in or near the following localities: Centerport, Cold Spring Harbor, East Northport, Greenlawn, Indian Head, Kings Park, Melville, Smithtown, and South Commack. In or near these localities individual wells screened in the Magothy (?), at depths ranging from 246 to 593 feet, yield from 600 to $1,700 \mathrm{gpm}$. The specific capacity of individual wells ranges from 16 to $86 \mathrm{gpm}$ per foot of drawdown and generally is somewhat lower than that of wells tapping water-bearing material in the Pleistocene deposits. The coefficients of transmissibility ${ }^{1}$ of the Magothy(?) water-bearing material were computed from the specific capacity (Theis and others, 1954) of typical public-supply wells. On the basis of these values of transmissibility and an estimated thickness of aquifer, the computed coefficients of permeability ${ }^{2}$ ranged from 450 to $750 \mathrm{gpd}$ per sq $\mathrm{ft}$ (table 3 ). In 1957, approximately 44 percent of the total withdrawal for public supply and industrial use in the HuntingtonSmithtown area was pumped from the Magothy(?) formation.

\footnotetext{
1 The coefficient of transmissibility is the rate of flow of water, in gallons per day, at the prevailing temperature, through each vertical strip of aquifer $1 \mathrm{ft}$ wide having a height equal to the thickness of the aquifer, and under a unit hydraulic gradient.

2 The coefficient of permeability is the rate of flow of water, in gallons per day, through a cross section of $1 \mathrm{sq} \mathrm{ft}$ under a unit hydraulic gradient at a temperature of $60^{\circ} \mathrm{F}$.
} 
HYDROGEOLOGY OF HUNTINGTON-SMITHTOWN AREA, N.Y. D19

TABLE 3.-Estimated permeability of water-bearing material in the Magothy(?) formation and Pleistocene deposits

\begin{tabular}{|c|c|c|c|}
\hline Well & $\begin{array}{l}\text { Screen zone (ft below } \\
\text { land surface) }\end{array}$ & $\begin{array}{c}\text { Specific } \\
\text { capacity } \\
\text { (gpm per ft) }\end{array}$ & $\begin{array}{c}\text { Permeability } \\
\text { (gpd per } \\
\text { sq ft) }\end{array}$ \\
\hline \multicolumn{4}{|c|}{ Magothy (?) formation } \\
\hline $\begin{array}{l}\text { S12079 } \\
\text { S13876 } \\
\text { S14521 } \\
\text { S15514 } \\
\text { S15515 } \\
\text { S16129 }\end{array}$ & 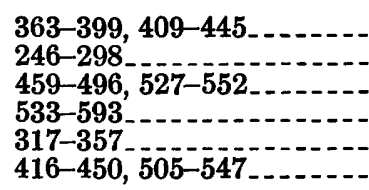 & $\begin{array}{l}50 \\
38 \\
86 \\
71 \\
16 \\
78\end{array}$ & $\begin{array}{l}550 \\
450 \\
750 \\
650 \\
450 \\
650\end{array}$ \\
\hline \multicolumn{4}{|c|}{ Pleistocene deposits } \\
\hline $\begin{array}{l}\text { S874 } \\
\text { S11105 } \\
\text { S11803 } \\
\text { S15746 } \\
\text { S15776 } \\
\text { S16049 } \\
\text { S16137 }\end{array}$ & $\begin{array}{l}100-130 \\
469-517 \\
164-217 \\
85-126 \\
438-501 \\
266-328 \\
540-602\end{array}$ & $\begin{array}{r}91 \\
31 \\
79 \\
62 \\
221 \\
90 \\
46\end{array}$ & $\begin{array}{r}900 \\
1,500 \\
900 \\
1,200 \\
1,000 \\
750\end{array}$ \\
\hline
\end{tabular}

PLIOCENE(P) SERIES

MANNETTO GRAVEL

The type area of the Mannetto gravel is the Mannetto Hills of eastern Nassau County. Crosby ${ }^{3}$ correlated these deposits with the Lafayette gravel of late Pliocene age. Fuller (1914, p. 85) considered the deposits to be remnants of a glacial outwash sheet of early Pleistocene age. The author has found no new evidence to support either interpretation of the age of this unit. The Geological Survey considers the Mannetto to be of Pliocene(?) age (Suter and others, 1949, footnote p. 9).

The Mannetto gravel has been identified by the author only in Huntington in exposures in the southern part of the West Hills where it rests on the buried Cretaceous surface. Other small outcrops were mapped by Fuller (1914, pl. 1) in the Dix Hills and several other places in the project area. These are not shown on plate 2 as the author was unable to confirm their presence. The Mannetto has also been correlated in a few well records (pl.4).

In surficial exposures in the West Hills, the Mannetto gravel is largely composed of current-bedded quartz sand and gravel and, in places, layers of clay. The sand grains and the pebbles are commonly pitted. Rarely, weathered igneous and metamorphic rock and ferruginous sandstone fragments are present in the deposits.

\footnotetext{
s Crosby, W. O., 1910, Report on the geological relations of the ground water of Long Island : Board of Water Supply, City of New York, unpub, rept., p. 52.
} 
The color of the Mannetto gravel ranges from light brown to orange brown. The preponderance of quartz and the scarcity of dark minerals and rock particles is characteristic of the Mannetto, as contrasted with the heterogenous composition of the upper Pleistocene deposits.

In most places the base of the Mannetto gravel rests on Cretaceous deposits at altitudes well above sea level (pl. 4). The Mannetto generally lies above the water table and consequently is of little importance as a source of water. Locally, however, some of the formation may lie in the zone of saturation and, in such places, may be a source of water. For example, well S4 (U.S. Geol. Survey, 1938, p. 12) reportedly penetrated 347 feet of sand and gravel that is probably partly of Mannetto age. The static water level in the well is reported to be 298 feet below the land surface. This unusually thick section of sand and gravel appears to lie in a narrow and steep-sided tributary of the Huntington buried valley. The floor of this tributary is near or slightly above sea level. Well $\mathbf{S 9 2 7}$ (Roberts and Brashears, 1945, p. 40), located north-northeast of well S4, penetrated 300 feet of coarse sand and gravel of probable Mannetto age before reaching the Cretaceous. Elsewhere, the Mannetto gravel has not been identified in deep wells, although it may be present in some buried valleys. Presumably, most of the Mannetto was dissected and removed by erosion prior to the deposition of the upper Pleistocene sequence.

\section{PLEISTOCENE SERIES}

Deposits of Pleistocene age mantle Cretaceous formations almost everywhere, but in a few places they rest on Pliocene(?) deposits. The thickness of the Pleistocene deposits ranges from 0 to more than 650 feet and averages 200 feet. Within the project area, these deposits may include three Pleistocene depositional sequences. The Jameco gravel and Gardiners clay, which are of post-Mannetto age, underlie deposits of the Wisconsin glacial stage in some deep buried valleys of northwestern Nassau County (Swarzenski, 1961, p. 33-34, and p. 42). Similar sequences have not been identified in the Huntington-Smithtown area, although some of the silt and clay bodies and the associated sand and gravel deposits in buried valleys may be equivalent to the Gardiners clay and the Jameco gravel. In this report these two formations are included with undifferentiated deposits largely of Pleistocene age that may also include deposits of Tertiary (?) age in some places. The bulk of the Pleistocene deposits belong to the latest sequence laid down during the Wisconsin glacial stage and are referred to in this report as upper Pleistocene deposits. 
The thickness and distribution of Pleistocene deposits were chiefly controlled by an older, now buried topography formed on the Cretaceous surface. This topography was the product of stream erosion, which probably began during the Tertiary and was later modified by overriding ice sheets and melt-water streams during the Pleistocene epoch. Information from well logs in the Huntington-Smithtown area indicates that a series of deep valleys were cut in the buried Cretaceous surface (pl. 3). Although the main buried valleys generally slope northward, major tributaries flow along eastwest lines-presumably along softer, less resistant beds in the Cretaceous.

Because of the lack of well data, the shape, depth, and extent of most of the buried valleys can be defined only approximately. In western Huntington the presence of a particularly deep valley (Huntington buried valley) was established from correlation of well logs and cores taken at wells S16137T, S14675T, S15190, and S16049T (pl. 4). At well S16137T, 604 feet of deposits of Pleistocene and possibly Tertiary age were penetrated without reaching the Cretaceous. This test well penetrated the greatest thickness of Pleistocene deposits known in the project area. . At well S14675T the basal gravel zone of the Magothy (?) formation was penetrated at 314 feet below sea level beneath 534 feet of post-Cretaceous deposits-probably all of Pleistocene age. The axis of this valley probably sloped northward, and in the northern reach of the valley the Magothy (?) formation and the clay member, and possibly even the Lloyd sand member, of the Raritan formation may have been completely removed by erosion. In the Northport area, evidence of another deep valley (Northport buried valley) was disclosed by core samples from well S11105, where 545 feet of Pleistocene deposits was penetrated to a depth of 370 feet below sea level. In Smithtown the axis of a deep buried valley is poorly defined, owing to lack of deep-well data. However, several wells (pl. 4) in this valley have penetrated Pleistocene deposits to depths as great as 300 feet below the land surface, of 185 feet below sea level.

The Pleistocene deposits are predominantly composed of stratified sand and gravel, although thick layers of nonmarine silt and clay occur in the buried valleys, and a thin surficial mantle of unstratified glacial till is common on the uplands north of the Harbor Hill terminal moraine. The sand and gravel are largely composed of quartz, but igneous and metamorphic rock fragments and biotite, hornblende, and augite are also generally present. The colors of the deposits are generally brown, yellow, or gray. An extensive Pleistocene clay unit has been identified in several wells in the major buried valley, which extends beneath most of Smithtown (pl. 4, and 
fig. 3). Locally, thick but discontinuous clay bodies of Pleistocene age also have been penetrated in wells in other parts of the project area. In general, they lie in the larger buried valleys, the floors of which are commonly below sea level. The clay unit of Smithtown and the other discontinuous clay bodies may include equivalents of the Gardiners clay, as well as glaciolacustrine deposits laid down during the Wisconsin glacial stage. All these clay deposits are intercalated with coarse sand and gravel.

The saturated sand and gravel beds in the Pleistocene deposits yield moderate to large supplies of water to properly constructed

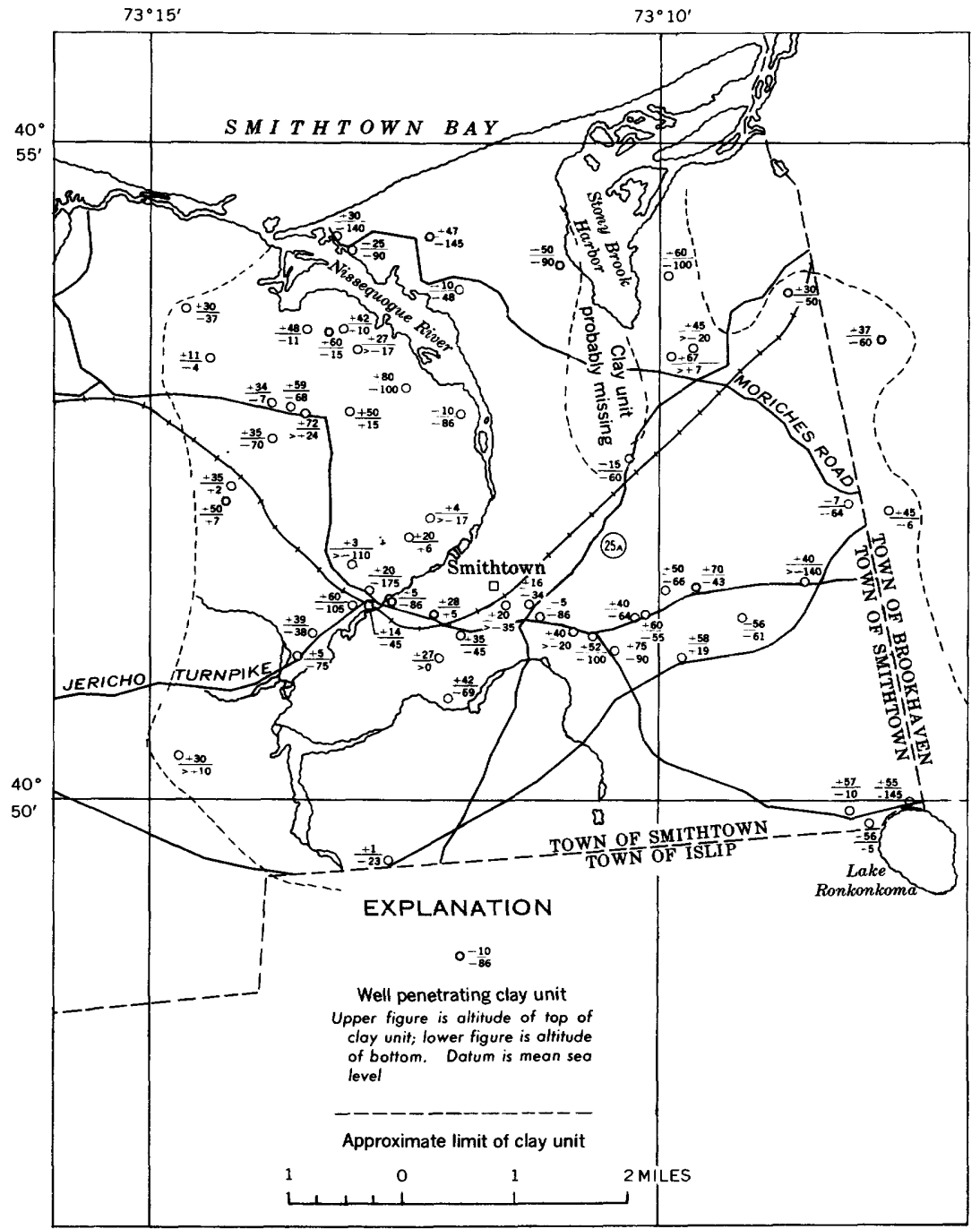

Frgurn 3.-Map showing approximate areal extent of the clay unit of Smithtown. 
wells, but the clay bodies act as local confining beds for waterbearing zones in Pleistocene sand and gravel and also in places for water in the Cretaceous deposits. The Pleistocene deposits constitute the most important source of water in the project area for numerous small domestic wells and also for industrial and publicsupply wells in and near the villages of Centerport, Dix Hills, Greenlawn Manor, Hauppauge, Huntington Station, Northport, and South Huntington. In these localities, individual public-supply wells screened in water-bearing sand and gravel beds of Pleistocene age at depths ranging from 100 to 602 feet yield from 1,000 to $1,700 \mathrm{gpm}$. Specific capacities of these wells range from 31 to $221 \mathrm{gpm}$ per foot of drawdown and on the average are higher than those of wells tapping the Cretaceous deposits. Transmissibilities of Pleistocene water-bearing materials tapped by typical public-supply wells were computed from specific capacities (Theis and others, 1954). By the use of these values and the estimated thickness of the aquifer, permeabilities ranging from 750 to $1,500 \mathrm{gpd}$ per sq $\mathrm{ft}$ (table 3) were computed. In 1957, ground-water withdrawals from wells screened in water-bearing sand and gravel of Pleistocene age accounted for 53 percent of the total pumpage for public supply and industrial use in the Huntington-Smithtown area.

UNDIFFERENTIATHD DEPOSITS OF PLEISTOCENE AND PLIOCENE(?) AGE

In some of the deeper buried valleys of the project area, wells have penetrated sections of sand and gravel associated with bodies of silt and clay that may include equivalents of the Gardiners clay and the Jameco gravel of Pleistocene age and possibly the Mannetto gravel of Pliocene(?) age. As these deposits cannot be identified or defined areally on the basis of available faunal and lithologic evidence, they are grouped in undifferentiated deposits of Pleistocene age.

At well S16137T (see following log) in the South Huntington well field, an unusually thick section of these undifferentiated deposits was penetrated between depths of 202 and 604 feet ( 47 to $449 \mathrm{ft}$ below sea level). The fine lignitic sand, silty clay, and clay between 202 and 407 feet may be an equivalent of the Gardiners clay. The remainder of the sand, gravel, silt, and clay sequence between 407 and 604 feet may include the Jameco gravel and possibly the Mannetto gravel.

At present (1960), well S16137 (pl.4) is the only well known to tap the undifferentiated deposits. This well, screened from 540 to 602 feet in fine to coarse sand containing some gravel and clay, yields $1,400 \mathrm{gpm}$ and has a specific capacity of $46 \mathrm{gpm}$ per foot of drawdown. 


\begin{tabular}{l|c} 
Thick- & $\begin{array}{c}\text { Depth } \\
\text { (feet) } \\
\text { ness } \\
\text { (feet) }\end{array}$ \\
\hline
\end{tabular}

S16137-T. (8E)

[South Huntington Water District, 5th Ave., South Huntington, N.Y. Drilled 1957 by C. W. Lauman and Co., lnc. Test well. Casing diameter 4 in, screen set from 180 to 185 ft. Alt $155 \mathrm{ft}$. Driller's log]

Recent deposits:

Sandy loam, gravel, and clay layers..... 6

Upper Pleistocene deposits:

Sand, coarse, and grit gravel, and clay layers; brown.

Sand, coarse, and gravel; brown

Sand, medium to coarse, and a little gravel; brown......

Sand, coarse, grit, and gravel; some clay; brown

Sand, coarse, grit and gravel; brown

Sand, fine to coarse, and some grit; brown

Sand, fine to coarse, and grit; some clay; brown . . . . . . .

Sand, coarse, and grit; some clay; brown ..............

Sand, fine to medium, and some clay; brown.

Sand, fine; some clay and layers of sandy clay; brown

Sand, medium to coarse, and some clay; brown. ..........

Pleistocene deposits undifferentiated:

Sand, fine, brown

Sand, fine, gray; lignite

Clay, sandy, gray.

Clay, gray; layers of silty gray clay....

Clay silty; layers of clay; gray.

Clay; layers of silty clay; gray.

Clay, gray -

Clay, sandy; layers of fine sand and gravel; brown

Clay, sandy, brown

Clay, sandy; layers of fine sand and clay; brown.

Sand. coarse, and grit; layers of sandy clay; brown

Clay, sandy, grit, and gravel; layers of coarse sand; brown

Sand, fine, and sandy brown clay

Clay, sandy, and grit; layers of fine sand; brown

Sand, fine, grit; and sandy clay; brown

Clay and sandy clay; layers of fine sand; brown

Sand, fine, and grit; some clay and sandy clay; brown......

Clay, sandy; layers of fine sand and grit; brown

Sand, fine, and sandy clay; brown . . . . . . . . . .

Sand, coarse, grit, and gravel; some clay; brown.

Sand, fine, and grit; layers of sandy clay; brown

Sand, medium, grit, and sandy clay; brown

Sand, medium, and grit; some clay and lumps of sandy clay; brown.

Sand, fine, brown

Sand, fine, and solid and sandy clay; brown

Clay, sandy; layers of medium to coarse sand and grit; brown.

Sand, fine, layers of sandy clay and gravel; brown

Sand, fine, brown

Clay, sandy, solid, and grit and fine to coarse sand; brown

Sand, coarse, brown

Sand, fine to coarse, brown

Sand, coarse, brown.

Clay, solid and sandy; layers of coarse sand and grit; gray ....

Sand, fine, clayey, gray; layers of sandy clay

Clay, sandy, gray

Sand, fine, brown.

Sand, fine, clayey, brown

Clay, solid and sandy, and fine sand; brown

Clay, sandy, layers of fine sand; brown..............

Clay, sandy, brown

Sand, fine, brown

Sand, medium to coarse, and grit; brown

40

94

6

10

9

10

10 
[South Huntington Water District. 5th Ave., South Huntington, N.Y. Drilled 1957 by C. W. Lauman and Co., Inc. Test well. Casing diameter 4 in, screen set from 180 to $185 \mathrm{ft}$. Alt $155 \mathrm{ft}$. 'Driller's log]

Pleistocene deposits undifferentiated-Continued

Sand, very fine, and sandy clay; streaks of clay; brown

Sand, coarse, grit, and gravel; brown

Sand very fine to fine, brown.

Sand, medium to coarse, brown

Clay and sandy clay; streaks of fine brown sand

Sand, coarse, grit, and gravel.

Sand, fine to coarse, git, and

Sand, medium to coarse, brown

Sand, fine, brown

Sand, medium to coarse; some grit; brown

Sand, fine to coarse, brown . . .

Sand, fine; layers of clay; brown

Sand fine, brown

\begin{tabular}{|r|l} 
& \\
6 & 511 \\
10 & 521 \\
5 & 526 \\
5 & 531 \\
5 & 536 \\
11 & 547 \\
4 & 551 \\
5 & 556 \\
6 & 562 \\
5 & 567 \\
9 & 576 \\
11 & 587 \\
4 & 591 \\
13 & 604 \\
\hline
\end{tabular}

\section{UPPER PLEISTOCENE DEPOSITS}

The upper Pleistocene deposits generally rest directly on the eroded surface of the Cretaceous deposits and form the bulk of the Pleistocene sequence in the Huntington-Smithtown area. In the northern part of the West Hills they lie on the Mannetto gravel of Pliocene(?) age, and in other places they lie on undifferentiated deposits of Pleistocene age. The upper Pleistocene deposits are thickest beneath the terminal moraines and in buried valleys, where in places they are more than 300 feet thick. The deposits include: (1) at least one and possibly two sheets of glacial till laid down directly as ground moraine by continental ice; (2) ice-contact deposits in the Ronkonkoma and Harbor Hill terminal moraines; (3) a considerable thickness of glaciofluvial deposits laid down by melt water streams in outwash plains and spillways during the advance, stagnation, and recession of the ice; and (4) discontinuous bodies of silt and clay laid down in glacial lakes and not exposed in the project area. The upper Pleistocene deposits are commonly brown, yellow, and gray.

A sheet of glacial till, generally less than 10 feet thick, forms a surficial mantle on most of the uplands of the project area north of the Harbor Hill end moraine. This till probably represents the ground moraine of the Harbor Hill ice. A second and older till sheet, largely buried but locally exposed in sand and gravel quarries in northwestern Nassau County, has been interpreted by Swarzenski (written communication, 1960) as the ground moraine of the Ronkonkoma ice. This till sheet also may be present in the Huntington-Smithtown area but has not been identified in outcrop or in well sections. 
The Ronkonkoma and Harbor Hill terminal moraines are largely composed of crudely stratified sand and gravel deposits showing slump and collapse features and containing isolated masses of till. Isolated or coalescing kames and interspersed kettles account for the irregular surface of these moraines.

The bulk of the upper Pleistocene deposits is composed of stratified coarse sand and gravel laid down by melt water streams. Thick discontinuous bodies of silt and clay, however, are common in the buried valleys (pl. 4). These bodies are probably glaciolacustrine deposits, which may have formed during the recession of the Ronkonkoma ice and prior to the advance of the Harbor Hill ice.

The "clay unit of Smithtown," which underlies much of Smithtown (fig. 3), was considered by H. R. Blank (written communication, 1928) to be a possible equivalent of the Gardiners clay. The author believes, however, that the unit is probably a glaciolacustrine deposit in the upper Pleistocene sequence and may have been laid down in a glacial lake or lakes during the wasting of the Ronkonkoma ice. This unit is in a large buried valley, which lies in the eastern part of Smithtown. Its areal extent is only approximately defined by well data. Local continuity, however, is indicated by several wells in the Smithtown and Kings Park area (pl. 4 and fig. 3). In the adjacent areas it was either not deposited or it was removed by later stream erosion. Its upper surface generally lies above sea level and reaches a maximum altitude of 70 feet. The thickness is variable and ranges from a few tens of feet to 200 feet. The unit is predominantly clay, but some lenses of sand containing gravel and silt are found locally. The clay unit is generally brown or gray, which is characteristic of the upper Pleistocene deposits.

In many places a water-bearing sand and gravel zone (pl. 4) underlies this clay unit and is tapped by wells. The coarser materials are generally below sea level, and probably extend down to the underlying Cretaceous surface. At well S11810 in Smithtown, the sand and gravel zone rests on the Magothy(?) formation and is about 70 feet thick. Presumably, the sand and gravel were deposited by melt water streams during the advance of the Ronkonkoma ice.

An upper zone of gravelly stratified deposits commonly rests on the higher parts of the Cretaceous surface and on the Pleistocene clay bodies. This zone generally consists of yellow and brown layers of medium sand to coarse gravel containing a few bouldersize rock fragments. Rock fragments of igneous and metamorphic origin also are typically present. Much of this zone is not water bearing, as it lies above the zone of saturation. 


\section{RECENT SERIES}

Deposits of Recent age are not extensive in the HuntingtonSmithtown area, and their thickness is rarely more than 20 feet. These deposits include beach sand and gravel, organic silt and clay in small ponds and marshes, and marine silt and clay in the northshore bays and harbors. A soil zone of variable texture and generally less than 5 feet thick blankets the Pleistocene and Cretaceous deposits. The soil is characteristically loamy in most of the area, although in the central part of Smithtown it is somewhat sandy.

The water-yielding potential of the Recent deposits is small, owing to small areal distribution and thickness. The sand and gravel in the beaches and tombolos generally yield only brackish water, but in places the water is relatively fresh and is tapped by shallow driven wells for domestic supply. The marine silt and clay deposits in the north-shore bays and harbors act as aquicludes, which retard the landward encroachment of salt water and confine underlying fresh water in the coastal zones.

\section{GROUND WATER}

All the fresh water that occupies the intergranular voids of the Cretaceous, Pliocene(?), and Pleistocene unconsolidated deposits constituting the ground-water reservoir above bedrock is ultimately derived from precipitation. Of the total precipitation, part runs off on the land surface, part returns to the atmosphere by evapotranspiration, and part seeps, down to the water table and replenishes the ground-water reservoir. Some of the water that reaches the water table circulates in the shallow part of the ground-water reservoir, but the rest moves down into the intermediate and deep parts of the reservoir, which, in places, is as much as several hundred feet below sea level. Water is discharged naturally from the reservoir by evapotranspiration in areas where the water table is close to the land surface, by effluent seepage into streams, and by upward leakage into salt water near the shoreline and offshore.

\section{WATER-BEARING UNITS}

Three discrete aquifers or water-bearing units have been recognized in the ground-water reservoir of the Huntington-Smithtown area. Each of these comprises parts of two or more of the stratigraphic units previously described and summarized in table 2. In addition, local bodies of ground water perched above the main water table have been observed at several places in the project area. The aquifers are defined chiefly by the hydraulic continuity deduced from the behavior of water levels in wells and by the degree of confinement of the water in the aquifer indicated by the 
presence or absence of extensive confining beds or aquicludes. In this report the aquifers are designated as shallow, intermediate, and deep. The shallow and intermediate aquifers are separated only imperfectly by discontinuous silt and clay bodies. The intermediate and deep aquifers are separated much more effectively by a silt and clay aquiclude, which is relatively thick and areally extensive. Consequently, water is interchanged much more readily between the shallow and intermediate aquifers than between the intermediate and deep aquifers. The characteristics and limits of the perched ground-water bodies, the three aquifers and their related water-table and piezometric surfaces, and the nature of water-level fluctuations in wells tapping these aquifers are described and discussed in following sections.

\section{PERCHED GROUND-WATER BODIES}

Discontinuous bodies of perched water are fairly common in the Huntington-Smithtown area. These generally lie on relatively thick layers of impermeable glacial till or on clay of Pleistocene age or on the Magothy (?) formation above the regional or main water table. The most extensive perched ground-water body occurs in the Harbor Hill end moraine in the northern part of the West Hills. Other perched bodies have been noted during the drilling of wells S16276 at Northport, S16880 at San Remo, and S16873 at Deer Park (pl. 1). Several wells that have tapped perched water bodies at altitudes as much as 200 feet above the main water table also are described by Veatch and others (1906, pl. 12). Wells S229 and S16876, both in West Neck, probably penetrate perched water bodies.

Domestic wells are generally not finished in perched water bodies, because yields are small and relatively undependable.

\section{SHALLOW AQUIFER}

The shallow aquifer generally includes saturated coarse sand and gravel in the upper Pleistocene deposits and, in some areas, hydraulically connected finer grained sand and gravel beds in the upper part of the Magothy(?) formation. Locally, saturated Mannetto gravel may also form part of the shallow aquifer. The shallow aquifer extends beneath the land area of the project, and it terminates at or near Long Island Sound. Fresh-water lenses in the shallow aquifer also occur on Lloyd Neck, Eatons Neck, and Little Neck. The aquifer extends from about 90 feet above to about 80 feet below sea level. Through this range, water in the aquifer is generally unconfined.

The upper limit of the aquifer is the regional or main water table (pl. 5). The lower limit is marked by discontinuous clay bodies, mostly in the upper Pleistocene deposits but in places in the Mag- 
othy (?) formation. In much of Smithtown a relatively extensive glaciolacustrine clay unit in the upper Pleistocene sequence forms the lower limit of the aquifer at levels ranging from about 70 feet above to 80 feet below sea level. In some parts of the project area, specifically where the buried Cretaceous surface (pl. 3) lies at altitudes above 100 feet, the Magothy(?) formation forms the entire shallow aquifer. Because of differences in permeability-lower in the Magothy(?) and higher in the Pleistocene-the hydraulic gradient within the aquifer may change markedly near the contacts of these two stratigraphic units.

Local ground-water bodies, which may be considered to represent detached segments of the shallow aquifer, are present on Lloyd Neck, Little Neck, and Eatons Neck. These bodies, shown by closed 5- and 10-foot contours (pl. 5), are sustained very largely by local recharge, and possibly also on Lloyd Neck and Little Neck by upward leakage from the intermediate and deep aquifers.

The configuration of the main water table in May 1959, shown in plate 5 , is based on water-level measurements in 51 observation wells and on water-surface altitudes observed in effluent streams and ponds that intersect the water table. Two prominent mounds on the main water-table divide of Long Island are present in the project area. The western mound includes all the broad area above the 70-foot contour in south-central Huntington, but only a small part of the eastern mound, above the 70-foot contour, is included in the easternmost part of Smithtown (pl. 5). Between these two mounds is a pronounced low, or trough, in the water table, which coincides roughly with the valley of the Nissequogue River. Two ground-water mounds represented by the closed 80 - and 90 -foot contours are present on the eastern high. The eastern mound (80-ft closed contour mostly north of well S16873) is apparently related to material of low permeability in the Magothy(?) formation which constitutes the shallow aquifer in this area. On the other hand, the western mound (90-ft closed contour) appears to be related to material of low permeability in the Pleistocene deposits.

North of the western mound, the water table slopes generally north toward Long Island Sound at gradients of about 15 to 30 feet per mile. However, southward deflections and reentrants in the 10- and 20-foot contours and local steepening of gradients are indicated near Cold Spring, Huntington, Centerport, and Northport Harbors (pl. 5). Between the western and eastern mounds the water table slopes generally toward the Nissequogue River at 20 to 30 feet per mile. North of the eastern mound the water table also slopes north toward the 
sound; a marked reentrant in the 10 - and 20 -foot contours is indicated near Stony Brook Harbor.

The water table is not static but fluctuates in response to changes in ground-water storage, particularly in the shallow aquifer. The most notable fluctuations are cyclical and are associated with the seasonal differences in the rates of recharge from precipitation and of discharge by evapotranspiration. Precipitation is generally evenly distributed throughout the year. During the colder months when evaporation and transpiration of plants are at a minimum, recharge from precipitation is at a maximum. Consequently, ground-water storage increases and the water table tends to rise. Conversely, during the warmer months when evaporation and transpiration are at a maximum, recharge is at a minimum. As a result ground-water storage is depleted by natural and artificial discharge and the water table declines. This phenomenon is illustrated in hydrographs of wells S1811, S1812 and S4827 (fig. 4) screened a short distance below the water table. The hydrographs show both long-term and seasonal cyclical trends and indicate that the water table normally declines during summer and autumn and rises during winter and spring. At well S1811 the water table is about 3 feet below land surface. The water-level fluctuations in this well are typical of a shallow water table at depths of less than 15 feet below land surface. The hydrographs for wells S1812 and S4827 indicate a water-table fluctuation of about 20 feet and 150 feet below land surface, respectively. The hydrograph (fig. 5) of well S8912, which is 28 feet deep, shows that there is a fairly close relation between water-table fluctuations and the monthly precipitation as recorded at the Lake Ronkonkoma rain gage. In this well the water table rises shortly after periods of high precipitation. Water-level fluctuations in deeper wells (S3514, fig. 5) in the shallow aquifer are not so directly related to short-term precipitation trends. At well S3514 the water table averages about 87 feet below land surface. Apparently, however, a relation exists with the long-term trends indicated by cumulative departure from average precipitation (fig. 5), at least from 1951 to 1958.

The water levels in shallow wells in the project area have been observed to fluctuate seasonably as much as 8 feet, but the average range is generally between 1 and 4 feet. These fluctuations result largely from the seasonal distribution of natural recharge from precipitation, from natural discharge by evapotranspiration, and by spring flow into streams and Long Island Sound. In 1960 there was little or no evidence of any long-term decline in the average position of the water table attributable to withdrawal from wells. 
HYDROGEOLOGY OF HUNTINGTON-SMITHTOWN AREA, N.Y. D31
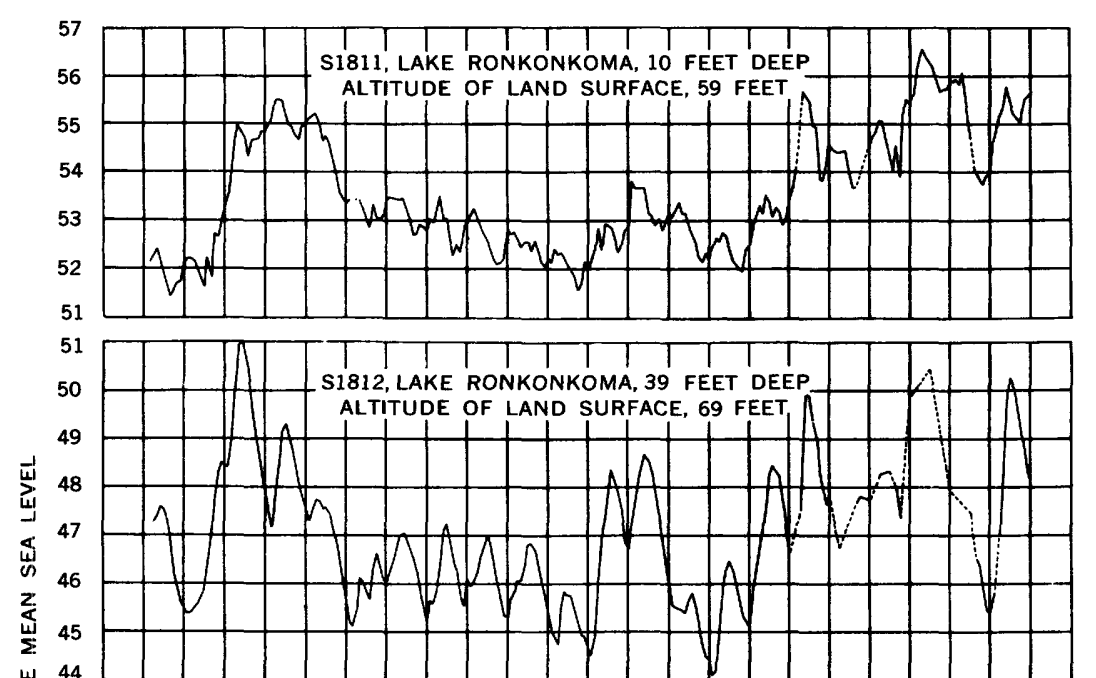

니 44

戛

$\ll$

嵌

㟧 60

z 59

岀 58

-

Q: 57

质 56

C) 55

u 54

를
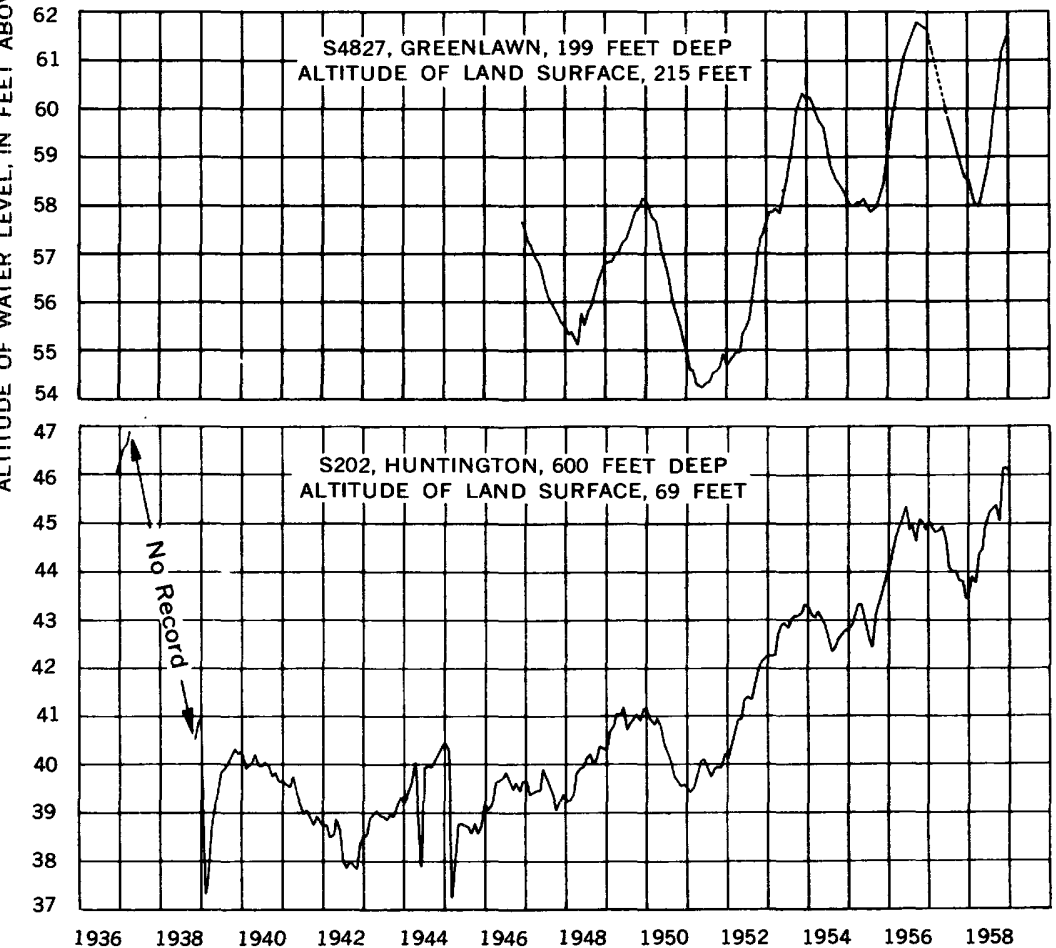

Figuri 4.-Hydnographs of three wells in the shallow aquifer and one well in the deep aquifer. 

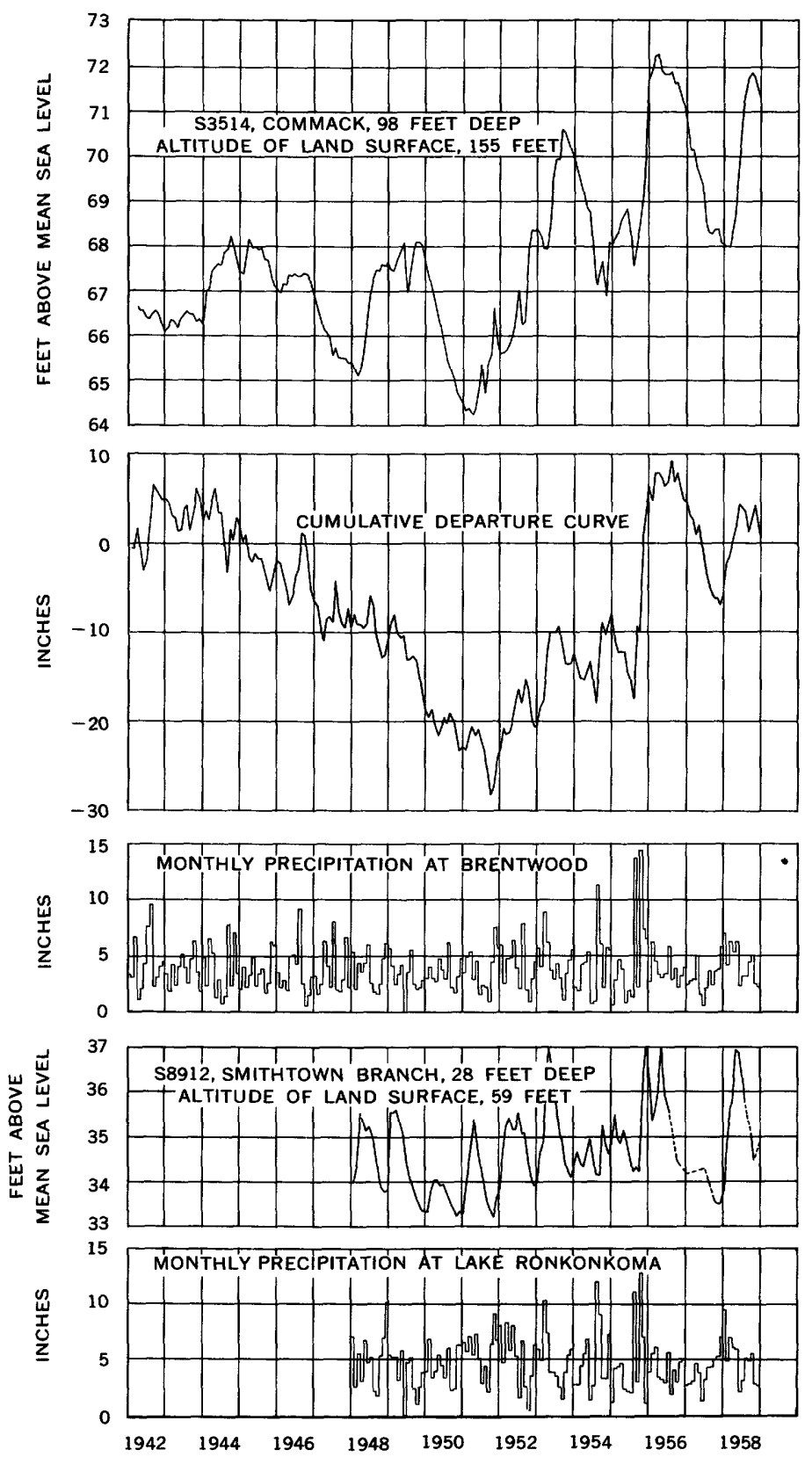

Figure 5.-Comparative hydrographs of two wells screened in the shallow aquifer, and monthly precipitation at Brentwood and Lake Ronkonkoma. 


\section{INTERMFDIATE AQUIFGR}

The intermediate aquifer includes most of the Pleistocene and possibly some Pliocene(?) deposits that lie in the deeper parts of the buried valleys and the bulk of the Magothy(?) formation down to the top of the clay member of the Raritan formation. The intermediate aquifer extends beneath virtually all the land area and possibly beneath much of Huntington Bay and the contiguous saltwater bodies. However, its hydraulic and chemical characteristics on Lloyd and Eatons Necks are poorly defined by present (1960) well data. Apparently, beneath Lloyd Neck it contains fresh water, but beneath most, if not all, of Eatons Neck the water in the aquifer is salty. The aquifer is nearly wedge shaped, and the thickness increases generally toward the south and southeast. Its minimum thickness, in the northwest part of the project area on Lloyd Neck, is less than 200 feet. Near the Half Hollow Hills (pl. 4), the aquifer is nearly 800 feet thick, and in the vicinity of Lake Ronkonkoma, it is about 600 feet thick. The top of the aquifer is irregular and is marked by discontinuous clay bodies both in the Pleistocene deposits and in the Magothy (?) formation. The altitude of the top ranges from about 60 to almost 200 feet below sea level. The lower limit of the aquifer, which coincides with the top of the clay member of the Raritan formation, ranges from 100 feet to more than 700 feet below sea level. Water in the aquifer is generally confined, but the confinement is more pronounced in its deeper parts.

The approximate configuration of the piezometric surface of the intermediate aquifer in May 1959 is shown in figure 6 by means of 10-foot contours referred to sea level. The surface as shown is approximate owing to lack of control data, particularly on Lloyd and Eatons Necks and elsewhere near the north shore and in the southern part of Huntington. This surface is a somewhat subdued replica of the water table (pl. 5). From a piezometric high represented by the 70-foot contour in south-central Huntington, the surface slopes south to the Atlantic Ocean and north to Long Island Sound at gradients of 5 to 15 feet per mile. A prominent depression on the surface is shown by the pronounced southward bending of the water level in the valley of the Nissequogue River.

As is characteristic in the ground-water reservoir of Long Island, the piezometric surface of the intermediate aquifer in the inland (southern) part of the project area is commonly 5 to 25 feet lower than the water table. This relation is reversed near the north shore where the piezometric surface is from 5 to 10 feet higher than the water table, as for example near Huntington, Centerport, and Northport Harbors. In the intervening belt, which lies approximately be- 


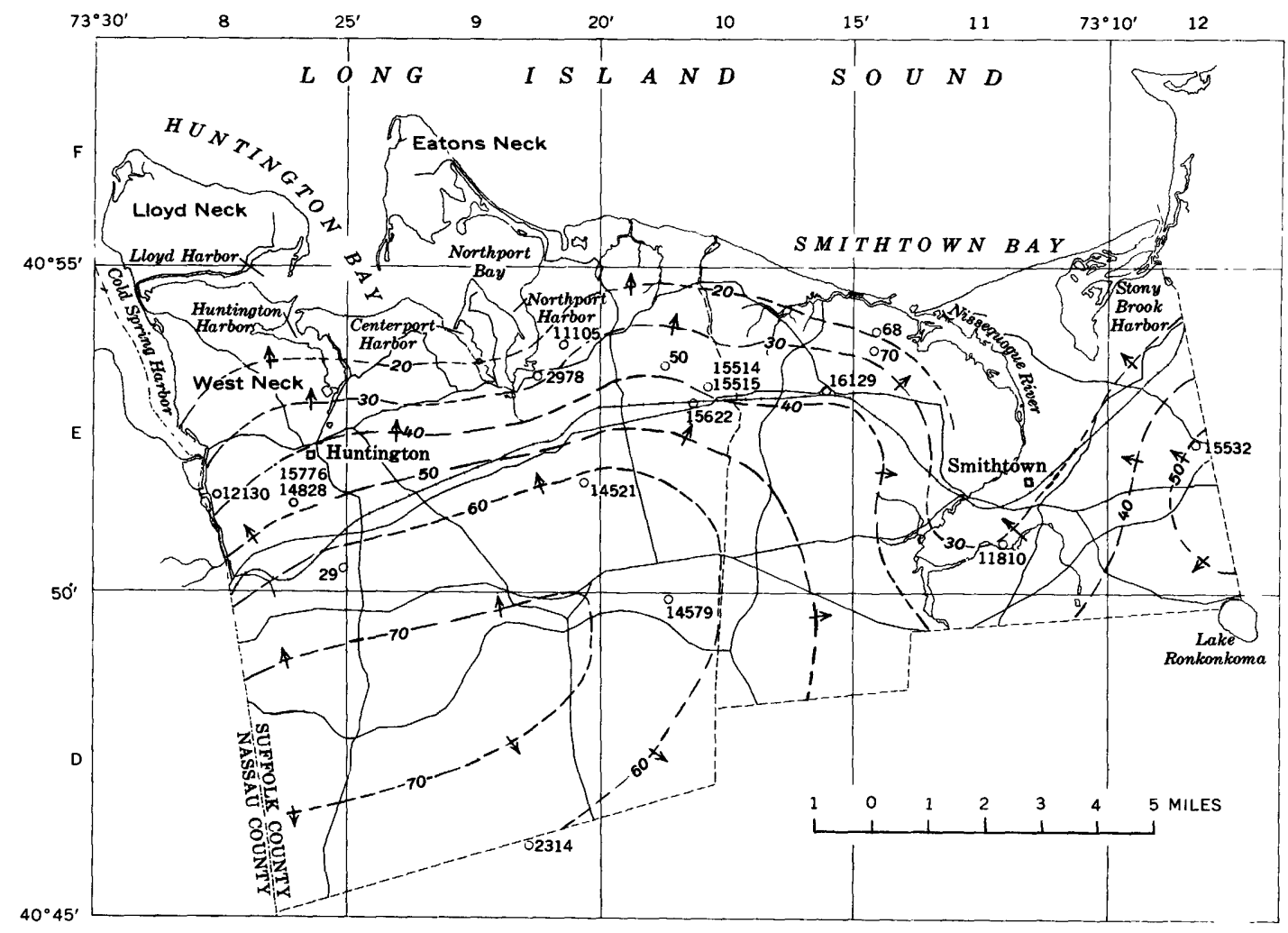

\section{EXPLANATION \\ 015622}

Observation well and number

----- -40--4---

Piezometric contour

Arrow indicates direction of ground-

water movement. Contour inter-

val 10 feet; datum is mean sea

FigUR 6.-Map of the Huntington-Smithtown area showing approximate contours on the piezometric surface of the intermediate aquifer in May 1959. 
tween the 40- and 50-foot piezometric contours (pl. 5), heads in both shallow and intermediate aquifers are virtually the same.

The "clay unit of Smithtown" acts as an effective aquiclude between the shallow and intermediate aquifers, which causes pronounced differences in head both locally and areally. Evidence of this condition is indicated by differences in head observed at wells S4377 and S15532 both located in Smithtown to the east of Saint James (pl. 1). Well S4377, which ends at 48 feet in the shallow aquifer above the clay unit, has a water level about 64 feet above sea level, and well S15532, which is screened from 181 to 196 feet in the intermediate aquifer below the clay unit, has a water level about 50 feet above sea level. Elsewhere in the project area, wells in the South Huntington Water District well field 1 also provide good examples of differences in head in wells in the shallow and intermediate aquifers (fig. 7) which are separated by a clay of Pleistocene age. The lateral extent of the clay beyond the well-field limit at South Huntington is not known. However, the clay may extend throughout much of the deep buried valley (Huntington valley, pls. 3 and 4). The water level in wells S28 and S29 (fig. 7), which are screened above and below the clay bed, respectively, have a head difference of 33 feet even though the vertical interval between the screens of the wells is only about 100 feet. Also, in well S16137T, screened near the bottom of the shallow aquifer, the head is 96 feet above sea level. In nearby well S16137, screened in the intermediate aquifer about 350 feet below the bottom of well S16137T, the head is about 50 feet above sea level, a difference of 46 feet.

Because water in the intermediate aquifer is confined, waterlevel fluctuations in wells screened in the aquifer generally indicate changes in artesian pressure. In wells screened in the shallow aquifer, the long-term or seasonal changes in pressure commonly follow with some lag the fluctuations of water levels. This relationship is shown in hydrographs (fig. 8) of wells screened in the shallow and intermediate aquifers. For example, comparison of the hydrographs of wells S28 and S29, which are at approximately the same site, suggests that the seasonal high water level in 1958 in the intermediate aquifer may lag several months behind corresponding changes in the shallow aquifer. The hydrographs of wells S3514, S14579 and S70 (fig. 8) also suggest a lag in fluctuations of several weeks to a few months. On the other hand, the fluctuations of water levels in wells S4268 and S15622 appear to be nearly synchronous, except for the period from December 1957 through February 1958. The reasons for the apparent similarity in part of the record are unknown. 


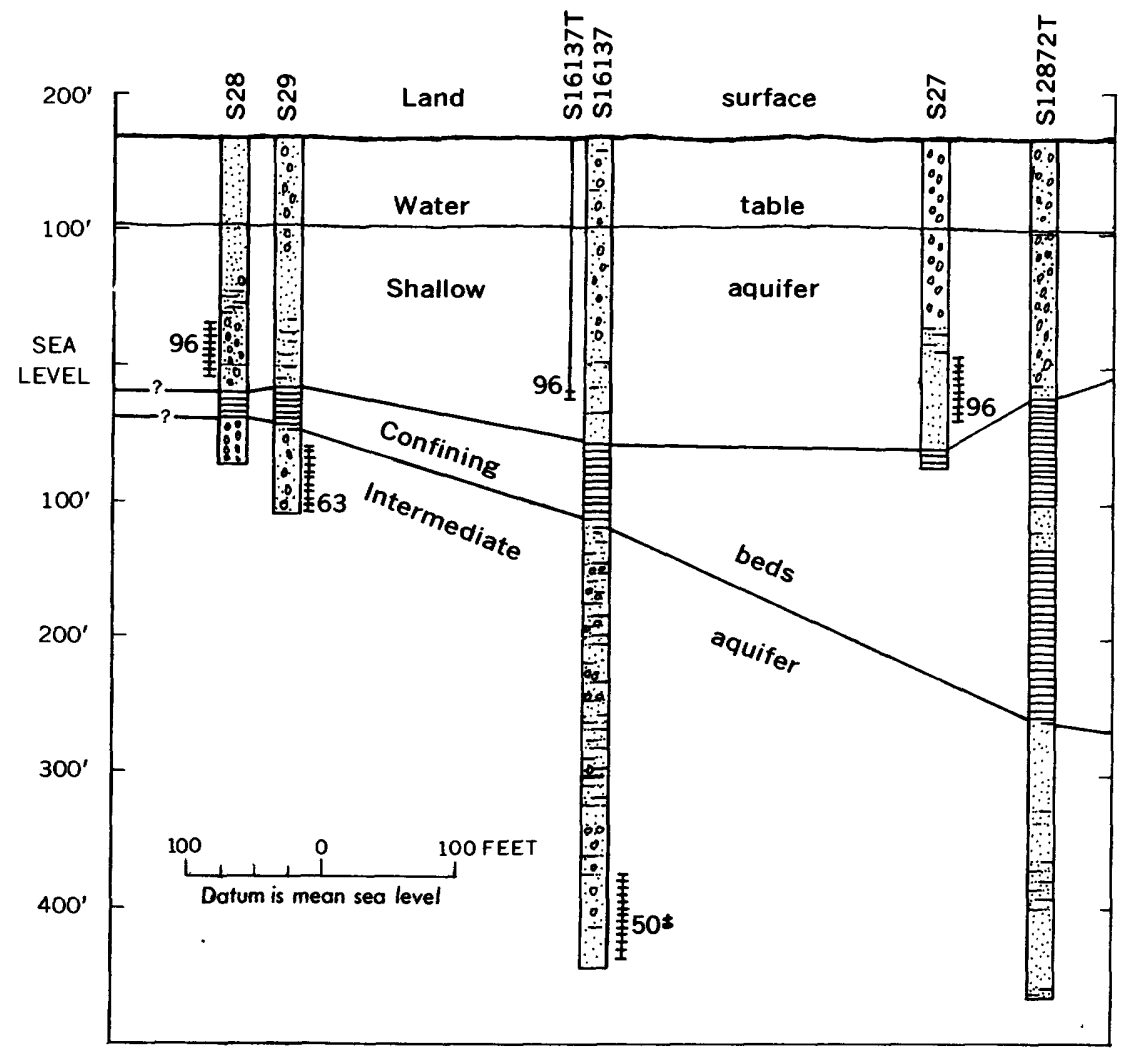

EXPLANATION

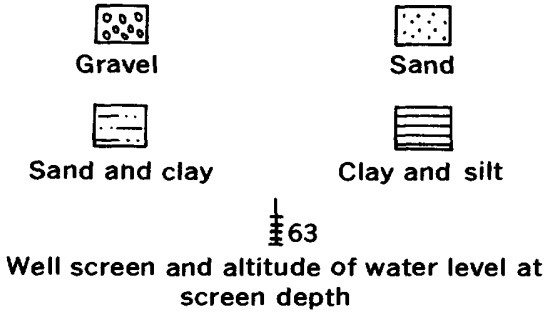

Frgori 7.-Hydrogeologle section through South Huntington Water District well field 1 showing head relationships in shallow and intermediate aquifers.

\section{DFFP AQUTFER}

The deep aquifer, which is almost everywhere coincident with the Lloyd sand member of the Raritan formation, lies beneath the entire project area. It also may extend beneath Huntington Bay and its contiguous inlets and harbors and beneath Lloyd and Eatons Necks. The deep aquifer beneath most of Lloyd Neck contains 
fresh water, but beneath Eatons Neck the water in the aquifer is probably salty. Locally, where the clay member of the Raritan formation has been removed by post-Cretaceous erosion, sand and gravel beds of presumed Pleistocene age are in hydraulic continuity with the Lloyd and form part of the deep aquifer. This condition probably exists in the deepest part of the buried Huntington valley (pl. 3 and 4) in western Huntington. Except where it is absent, the clay member of the Raritan overlies the Lloyd and acts as a thick and laterally extensive aquiclude which retards movement of water into and out of the Lloyd. Where the clay member is absent, clay bodies in the lower part of the Pleistocene sequence act as acquicludes, which confine water in the deeper Pleistocene sand and gravel and in the hydraulically contiguous Lloyd. Of the three aquifers in the project area, the deep aquifer is hydraulically the most perfectly confined.

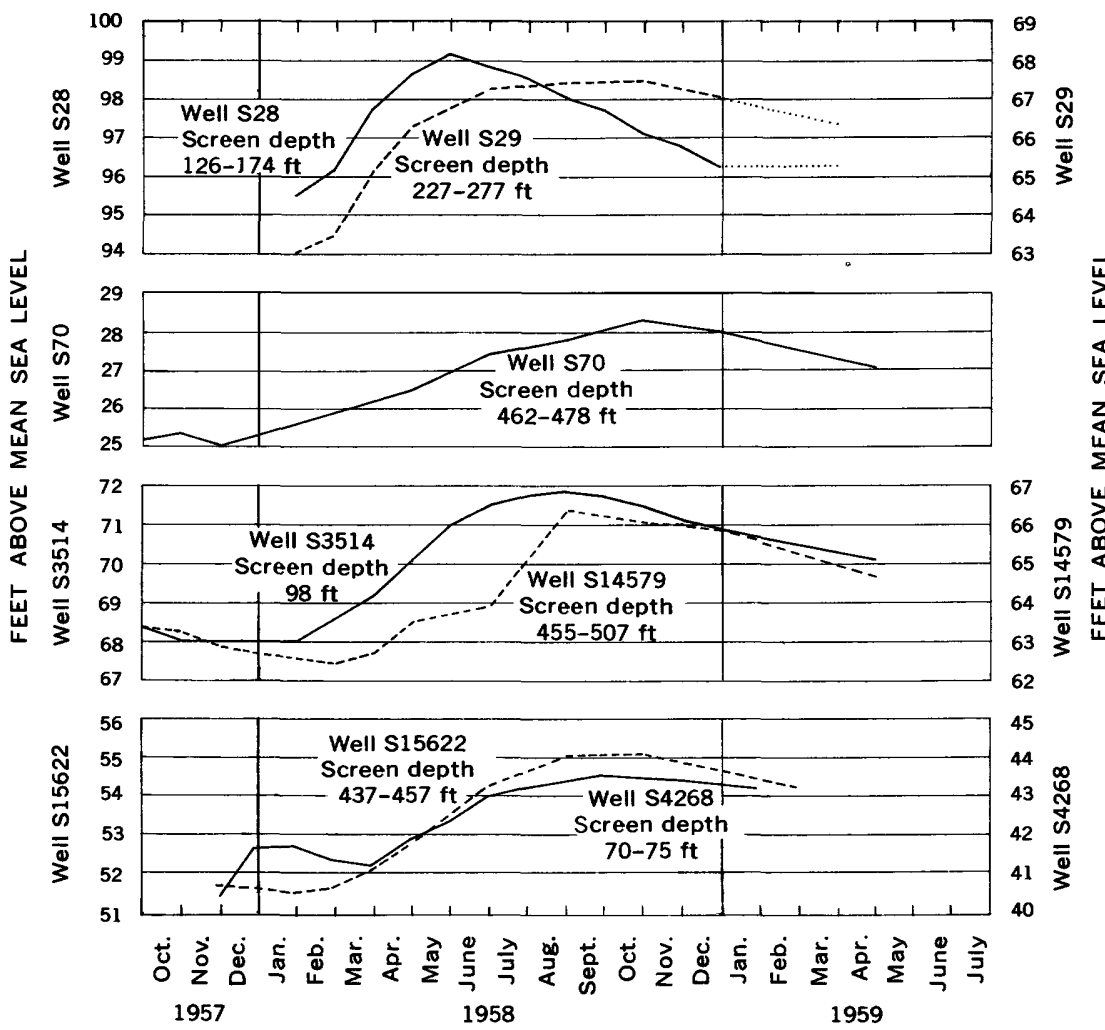

EXPLANATION

Shallow aquifer $\begin{gathered}\text { Intermediate } \\ \text { aquifer }\end{gathered}$

Figdor 8.-Comparative hydrographs of wells screened in the shallow and intermediate aquifers. 
Because of scanty well data, it is not possible to construct an accurate map of the piezometric surface of the deep aquifer. Data are lacking at present (1960) for Smithtown and the southeastern part of Huntington. Furthermore, the piezometric surface shown in figure 9 for the northern and western part of Huntington is only approximate as points of control are scattered. As shown, the piezometric surface of the deep aquifer is at maximum altitudes of somewhat more than 50 feet in west-central Huntington. From the piezometric divide, which is between the 50 -foot contours, the surface slopes north and south to sea level at gradients of about 5 to 15 feet per mile. Comparison of the shapes of the piezometric surfaces of the intermediate and deep aquifers (figs. 6 and 9) suggest that the piezometric divide of the deep aquifer lies about 2 to $2 \frac{1}{2}$ miles north of the piezometric divide of the intermediate aquifer. This condition apparently is a function of the asymmetry in crosssectional profile of Long Island's ground-water reservoir, whose thickness on the south shore is three or more times greater than it is on the north shore. In the project area the highest observed head in the deep aquifer was about 46 feet above sea level at well S202 in Huntington, and the lowest was 10 feet above sea level at well S4466 on Lloyd Neck.

In the southern part of Huntington the piezometric surface of the deep aquifer is 20 to 30 feet lower than that (fig. 6) of the intermediate aquifer, but in the vicinity of the northern 50-foot contour (fig. 9) the heads in the two aquifers are virtually the same. North of this contour the heads of the deep aquifer become progressively higher than those of the intermediate aquifer. Thus, in the vicinity of Huntington, Centerport, and Northport Harbors, piezometric heads of the deep aquifer are 5 to 10 feet higher than those of the intermediate aquifer.

Fluctuations of artesian pressure in the deep aquifer generally reflect seasonal trends similar to those of the water table, particularly where the water table is more than 100 feet below land surface. This relationship is shown by the hydrographs (fig. 4) for well S4827 screened in the shallow aquifer and well S202 in the deep aquifer. The minor irregularities in the overall water-level trend of the hydrograph of well S202 are probably caused by interference effects from pumping at public-supply wells $\mathrm{S} 8$ and $\mathrm{S} 1313$, which are also screened in the deep aquifer and are located about 1 mile north of well S202.

Short-term fluctuations in head also occur in wells screened in the intermediate and deep aquifers as a result of changes in load on confining strata. Fluctuations of this nature result from changes in atmospheric pressure, earth tides, earthquakes, and passing railroad trains. Such fluctuations are small, generally less than 0.1 


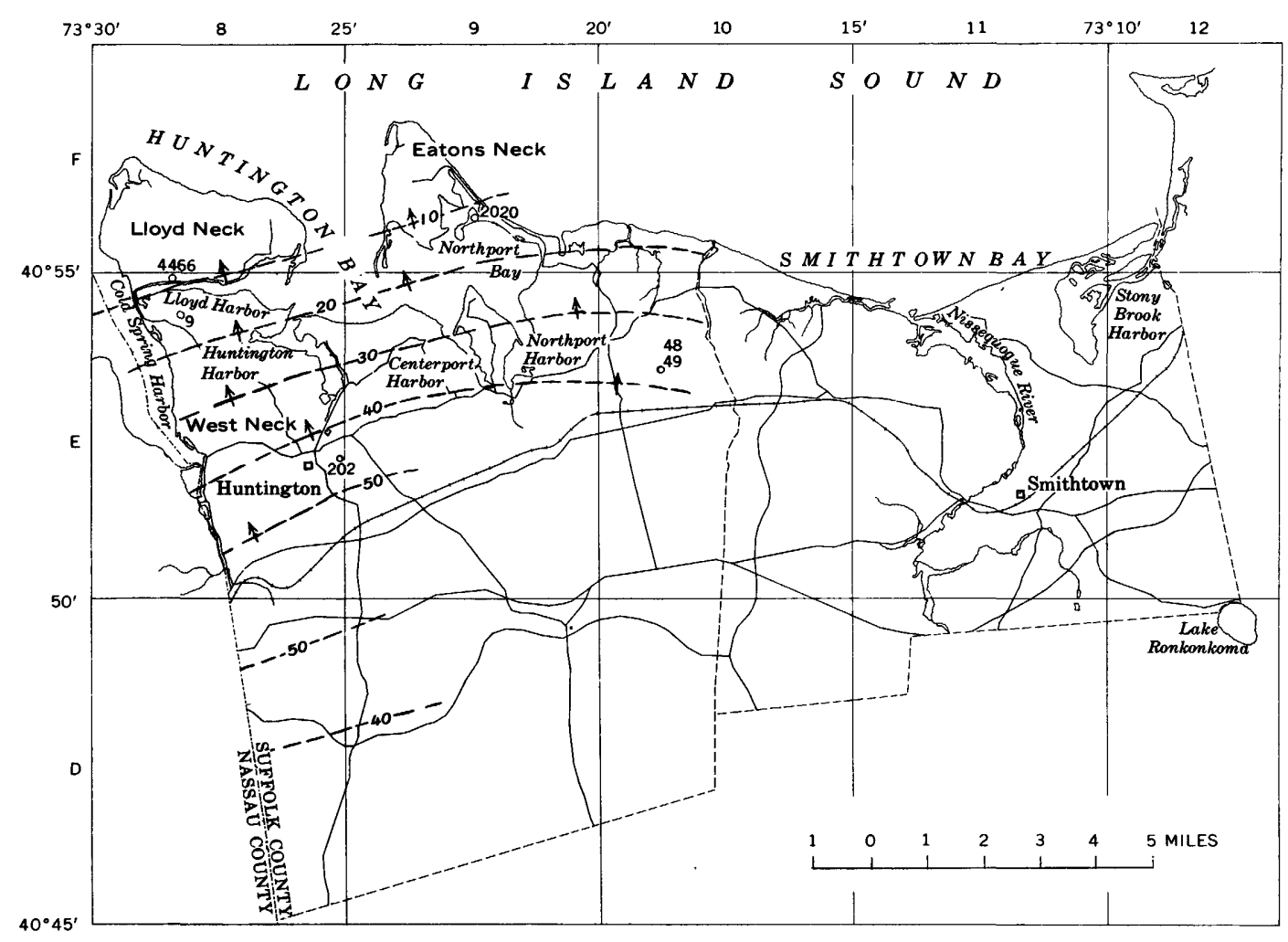

Piezometric contour

Arrow indicates direction of ground water movement. Contour interval 10 feet; datum is mean sea

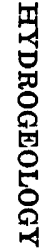


foot, and are commonly masked by fluctuations of larger amplitude. Cyclical fluctuations in pressure also result from ocean tides, particularly in wells screened in the intermediate and deep aquifers near Long Island Sound. For example, at well S2020 located on a promontory between Duck Island Harbor and Northport Bay and screened in the deep aquifer, water-level fluctuations caused by tidal loading have a daily amplitude of as much as 3 feet between high and low tide. Tidal changes in Lloyd and Cold Spring Harbors also influence the water levels of wells S9 and S4466, both of which are screened in the deep aquifer.

\section{RECHARGE}

All the fresh water in the ground-water reservoir of the project area, as well as the rest of Long Island, is derived from precipitation. However, only a part of the total precipitation that falls reaches the water table. The amount which percolates down to the water table and recharges the reservoir is the residual of the total precipitation not returned to the atmosphere by evapotranspiration or lost to the sea by overland runoff. Owing to the highly pervious nature of the soil and the substrata and to the gentle slopes of the land surface, infiltration is relatively high. Of an average annual precipitation on the project area of 49 inches, 21 inches, or about 43 percent, is estimated to reach the water table.

The catchment surface on which recharge presumably takes place includes most of the land area of the project, or about 146 square miles. This catchment includes Lloyd and Eatons Necks but does not include an additional 7 square miles of high water table and tidal marshes which fringe the northern shoreline. A considerable part of the catchment area, however, is made impervious by buildings and pavements, but much of the runoff from such covered areas is recovered in storm water disposal (recharge) basins or large-diameter diffusion wells. The natural recharge from precipitation on the project area, exclusive of the high water-table areas, the tidal marshes and of Lloyd and Eatons Necks, is estimated to average about $140 \mathrm{mgd}$ (million gallons per day). In addition, the recharge on Lloyd Neck is estimated to average about $5 \mathrm{mgd}$ and on Eatons Neck about $2 \mathrm{mgd}$. The total for the project area then would be about $147 \mathrm{mgd}$. The rate of natural recharge varies greatly from season to season and from year to year depending on such factors as evapotranspiration, air and soil temperatures, soil-moisture conditions, and the nature and seasonal distribution of precipitation. During dry years, recharge is substantially less than average, and conversely in wet years it is more. 
Natural replenishment of the intermediate and deep aquifers takes place entirely by downward movement of water from the shallow aquifer through discontinuities in clayey and silty beds and probably directly by slow movement through these aquicludes. Recharge of the intermediate aquifer probably occurs chiefly in the areas where the water table lies above an altitude of about 60 feet (pl. 5). The deep aquifer, in turn, receives recharge by downward leakage from the intermediate aquifer through an extensive aquiclude formed chiefly by the clay member of the Raritan formation. This recharge, which probably proceeds at a very slow rate, occurs chiefly where the piezometric surface of the intermediate aquifer lies above an altitude of about 60 feet (fig. 6 ).

Artificial recharge of the ground-water reservoir is effected by means of cesspools and septic tanks, which ultimately receive most of the water pumped from public-supply and domestic wells. For example, during 1957 an estimated average of about $9.8 \mathrm{mgd}$ was returned to the ground by this means in the project area, and at the same time about $2.5 \mathrm{mgd}$ was discharged directly into Long Island Sound through sewage disposal systems at the villages of Huntington and Northport and at Kings Park State Hospital. Also, as required by law, an average of about $0.7 \mathrm{mgd}$ of water pumped from privately owned wells for industrial and cooling purposes during 1957 was returned to the ground through sumps and diffusion wells.

\section{MOVEMENT}

In the ground-water reservoir, water moves vertically and laterally from points of high head to points of low head along flow lines whose direction is normal to the contour lines shown for the water table (pl. 5) and the piezometric surfaces (figs. 6 and 9). Water in the shallow aquifer flows away from the two major highs on the main watertable divide of Long Island, represented by areas above the 70-foot watertable contour in south-central Huntington and eastern Smithtown (pl. 5). The general directions of ground-water flow are north toward the Long Island Sound, south toward the Atlantic Ocean, and also a pronounced lateral movement toward the trough in the valley of the Nissequogue River. Local directions of flow, which may deviate substantially from these general directions, are indicated by arrows on the water-table contours (pl. 5). Also, the peninsulas of Lloyd, Eatons, and Little Necks each contain a groundwater mound in the shallow aquifer and from the crests of these mounds the shallow ground water moves laterally outward to bounding salt-water bodies. Within the area circumscribed by the 60 -foot water-table contour (pl. 5), a downward head differential generally exists between the shallow and intermediate aquifers. Conse- 
quently, downward movement of water from the shallow aquifer to the intermediate aquifer takes place.

The piezometric surface of the intermediate aquifer (fig. 6) indicates horizontal components of ground-water movement, which are generally similar to those in the shallow aquifer but apparently not so irregular. North of the 30 -foot piezometric contour (fig. 6) there is commonly an upward head differential between the two aquifers which causes movement of water from the intermediate aquifer to the shallow aquifer, particularly in the coastal zones of Long Island Sound and of contiguous bays, harbors, and inlets, and probably also in the lower part of the Nissequogue River valley.

The directions of the lateral component of flow in the deep aquifer and in the intermediate and shallow aquifers are apparently similar. Pressure heads in the deep aquifer, however, are known only at a few scattered points in Huntington. Consequently, the piezometric surface (fig. 9) can be defined only approximately in western and northern Huntington. A downward head differential between the intermediate and deep aquifers exists within the 60 -foot intermediate piezometric contour (fig. 6). Consequently, movement of water from the intermediate to the deep aquifer is possible within most of this area. However, north of the northern 50-foot piezometric contour of the deep aquifer (fig. 9) in the vicinity of Huntington, Centerport, and Northport Harbors and beyond, an upward head differential between the intermediate and deep aquifers causes movement of water from the deep to the intermediate aquifer. Because of the northerly position of the piezometric divide in the deep aquifer with respect to correlative divides in the intermediate and shallow aquifers, a large percentage of the water received by the deep aquifer apparently moves southward to the Atlantic Ocean, and the lateral movement of ground-water flow in the intermediate and deep aquifers is actually in opposite directions through a belt about 1 to $11 / 2$ miles wide. This condition is suggested by a comparison of figure 6 with figure 9, which indicates a northerly flow of ground water in the intermediate aquifer and a southerly flow in the deep aquifer.

The direction of ground-water flow and head relations in the ground-water reservoir are illustrated in the hydraulic profile in figure 10, which was prepared on the basis of water-level measurements and geologic data in several wells located along section $X-X^{\prime}$, (pl. 5). The equipotential lines are indicated for only the shallow and intermediate aquifers, as hydraulic data for the deep aquifer were not available in the line of profile. The flow direction, indicated by arroys, is generally parallel to the plane of the section. The effects of several thick aquicludes in the northern part of section $X-X^{\prime}$ on the direction of ground-water flow are indicated in 


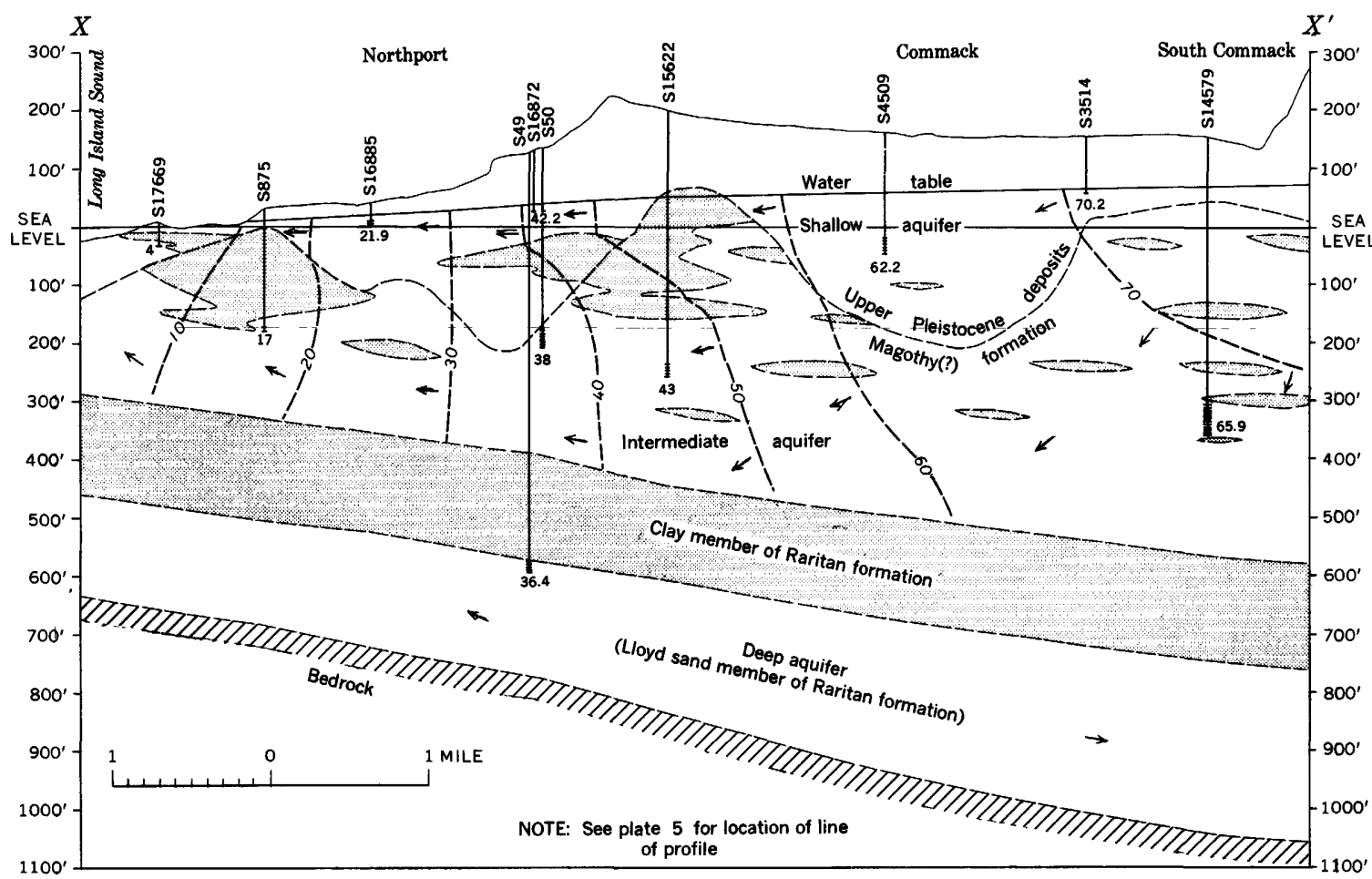

EXPLANATION
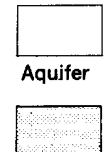

Aquiclude

- - $10--$

Trace of equipotentia surface on plane of section

Ground-water flow

$$
\text { S50 }
$$
Well number

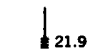

Well screen

Water level in feet

Wave level

Figdre 10.-Hydraulic proflle through ground-water reservoir along section $X-X^{\prime}$ from Northport to South Commack, N.Y. in May 1959 . 
figure 10 by deflections in the equipotential lines. The contiguous clay bodies in the Pleistocene and Magothy(?) deposits form a common aquiclude.

The velocity of flow through the ground-water reservoir is as important as direction of movement, particularly with reference to the dilution and dispersal of contaminants that may move in solution in the water. The velocity is a function chiefly of permeability, hydraulic gradient, and porosity as indicated by the following formula:

in which,

$$
\nabla=\frac{P l}{7.48_{p}},
$$

$V=$ velocity, in feet per day;

$P=$ coefficient of permeability, in gallons per day per square foot;

$I=$ hydraulic gradient, in feet per foot;

$p=$ porosity, in percent.

Computations based on the foregoing formula-using values for permeability, natural hydraulic gradients, and porosity, which seem appropriate to the water-bearing units of the Huntington-Smithtown area-suggest the following range in natural velocities.

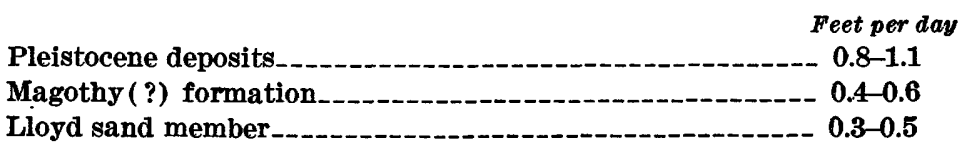

The indicated differences in velocity result chiefly from differences in overall permeability among the three units. However, maximum natural velocities in the more permeable facies of all these units may be far greater than those just indicated, but minimum velocities may be considerably less. Moreover, pumping from wells creates cones of depression in which hydraulic gradients are greatly increased over those prevailing under natural conditions. Consequently, velocities in the vicinity of pumping wells may be as much as 100 times greater than velocities under natural gradients.

\section{DISCFARGE}

Water discharges naturally from the ground-water reservoir by evapotranspiration, the flow of coastal springs, submarine discharge into salt-water bodies, and effluent seepage into streams draining into Long Island Sound. Water is also discharged artificially by by pumping from wells.

The annual rate of total evapotranspiration on Long Island is estimated to range from about 22 to 26 inches on the basis of studies by Williams (1940, pl. 2), Meyer (1944, p. 239-281), and Thornthwaite (1939). Of the total evapotranspiration, part is water from precipitation that is intercepted and returned to the atmosphere before 
reaching the water table, but part is water discharged directly from the ground-water reservoir where the water table is at or near the land surface. Evapotranspiration directly from the ground-water reservoir occurs in most of the areas of high water table, meadow and swamplands, and tidal marshes that fringe the shore of Long Island Sound. These areas are estimated to cover a total of about 7 square miles and to have an average evapotranspiration rate of 24 inches annually, or about $8 \mathrm{mgd}$.

Numerous springs discharge at the edge of the salt water along the shore of Isong Island Sound. The flow of individual springs where it can be observed is generally less than $10 \mathrm{gpm}$, but the aggregate discharge from such springs may amount to several million gallons a day. All this discharge apparently issues from the shallow aquifer. Submarine discharge by upward leakage from the intermediate and deep aquifers probably takes place mostly in Long Island Sound and in contiguous bays and harbors. Such submarine outflow cannot be observed or measured directly but probably makes up the bulk of the water naturally discharged from the ground-water reservoir north of the water-table and piezometric divides.

A considerable volume of ground water also discharges naturally by seepage into effluent streams such as Cold Spring Brook, Nissequogue River, Mill Creek, and Stony Hollow Run, which all flow into Long Island Sound. The aggregate flow, most of which represents ground-water discharge, from gaged streams draining the project area was estimated to average about $30 \mathrm{mgd}$ during the period of record (table 4).

Artificial withdrawal of water from the ground-water reservoir takes place through pumping or flowing wells. In 1957 gross withdrawals for all purposes within the project area were estimated to average about $14.7 \mathrm{mgd}$. Of the water withdrawn, an estimated average of $10.5 \mathrm{mgd}$ was returned to the ground through recharge wells, sumps, cesspools, and septic tanks. About $2.5 \mathrm{mgd}$ of used ground water was delivered directly to Long Island Sound and the Nissequogue River through sewage-disposal systems. Presumably, the residual of $1.7 \mathrm{mgd}$ was used consumptively in industrial processes and sprinkler irrigation.

\section{PUMPAGE}

Ground-water withdrawals from wells in the Huntington-Smithtown area have steadily increased with the rapid growth of population and industry during the past two decades. In 1960 practically all water requirements for public supply and for industrial, domestic, and agricultural purposes were supplied from ground water. Most of the pumpage data given in this report were obtained from the New 
York State Water Resources Commission, but some data were obtained from miscellaneous private sources. A complete record of pumpage for public supply in Suffolk County had been maintained by the commission since 1950. Most of the pumpage is metered, but some is estimated. Industrial pumpage includes withdrawal for industrial, commercial, institutional and estate needs. Records for this pumpage are not as accurate as those for public supply, and therefore the annual pumpage per well is generally estimated. A partial record of agricultural pumpage is also filed with the commission.

During the period 1932-57, average withdrawals from public-supply systems in the Huntington-Smithtown area increased from about 1.5 mgd in 1932 to $8.8 \mathrm{mgd}$ in 1957 (fig. 11). The rate of withdrawals from public-supply systems has increased so sharply since about 1949 , that by 1957 about 75 percent of the population of the project area was supplied by public-supply systems. In 1957, some 14 municipally owned and privately owned public-supply systems served the Huntington-Smithtown area, and the average withdrawals from individual systems ranged from an estimated 0.1 to $3.7 \mathrm{mgd}$. Metered

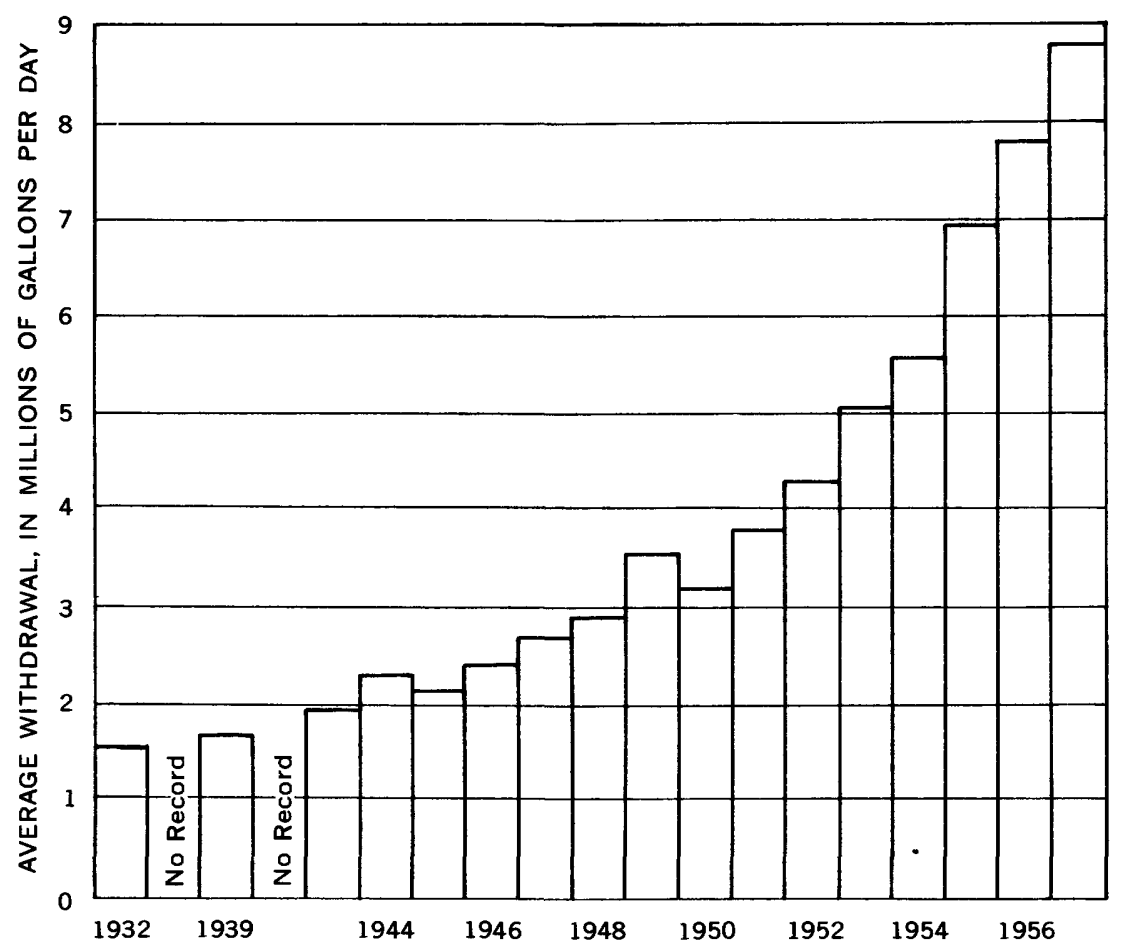

Froon 11.-Average withdrawal from public-supply systems in the Huntington-Smithtown area, $1932-57$. 
or estimated pumpage during 1957 for public-supply wells is shown graphically in plate 6. Most of the draft was from wells screened in Pleistocene deposits at depths ranging from 40 to 504 feet below land surface, but at the same time the draft from wells screened in the Magothy (?) formation was substantial. In 1957, only two public-supply wells, S8 and S1313, were drawing water from the deep aquifer (Lloyd sand member). The average withdrawal for public supply in 1957 was $8.8 \mathrm{mgd}$, of which $5.5 \mathrm{mgd}$ or 63 percent was pumped from Pleistocene deposits, $3.0 \mathrm{mgd}$ or 35 percent from the Magothy(?) formation, and about $0.3 \mathrm{mgd}$ or 2 percent from the Lloyd sand member.

Domestic wells supplied an estimated 25 percent of the population of the project area during 1957 and accounted for an average withdrawal of about $2.2 \mathrm{mgd}$ based on an estimated daily use of 76 gallons per person (Hoffman, 1959, p. 35).

The industrial pumpage during 1957 was estimated to average about $2.7 \mathrm{mgd}$ of which $0.7 \mathrm{mgd}$, or 26 percent, was ultimately returned to the ground-water reservoir by means of diffusion wells or sumps. The Northport Veterans Hospital and the Kings Park State Hospital account for about 60 percent of the industrial pumpage. Of the withdrawal for industrial use during 1957 , about $2.0 \mathrm{mgd}$ was pumped from the Magothy (?) formation, $0.6 \mathrm{mgd}$ from the Pleistocene deposits, and $0.1 \mathrm{mgd}$ from the Lloyd sand member.

Pumpage classified under agricultural use in the project area is used almost entirely for irrigation. Most of this withdrawal takes place during June, July, and August, ${ }^{4}$ although irrigation may start as early as May and at times may continue into October. In 1957. the agricultural pumpage reported to the New York State Water Resources Commission for the Huntington-Smithtown area was 140 million gallons, which was used to irrigate about 713 acres. However, a total farmed acreage of 1,852 acres, most of which is irrigated, had been reported previously to the commission. The estimated agricultural pumpage for the total reported irrigated acreage in 1957 was about 364 million gallons. Owing to the sprinkler method of irrigation which is practiced in the area, most if not all of the water used for irrigation is probably dissipated into the atmosphere by evapotranspiration.

The distribution of pumping during 1957 from public-supply and industrial wells at principal centers of pumping is shown in figure 9. As indicated, centers of pumping are fairly evenly distributed in Huntington, but the bulk of the pumping in Smithtown is concen-

\footnotetext{
- New York State Water Resources Commission, 1958, Report of Long Island groundwater withdrawal for 1957 and 10-year summary of water consumption from all sources: New York State Water Resources Comm., duplicated rept., p. 5.
} 
trated in the Kings Park area. In Huntington it is noted that several centers of moderately heavy withdrawal are located near the southern extremities of Cold Spring and Huntington Harbors and also in the vicinity of Centerport and Northport Harbors. However, the draft from wells at these centers at present (1960) rates has not resulted in any apparent overdevelopment of the ground-water reservoir nor is there any evidence of sea-water encroachment. Withdrawals in the Huntington-Smithtown area averaged about $14.7 \mathrm{mgd}$ in 1957 and are listed by major use, as follows:

Use

Public supply

Domestic $^{1}$

Industrial ${ }^{1}$

Agricultural ${ }^{1}$

Total
Withdrawals

(mgd)

8. 8

2.2

2. 7

1.0

14. 7 .

\section{Estimated.}

Note.-As discussed on page D45, only about $4 \mathrm{mgd}$ of the total withdrawal of 14.7 mgd represents a net loss of ground water, as the remainder recharges the groundwater reservoir through cesspools, pits, and wells.

\section{SURFACE WATER}

The larger streams and some of their smaller tributaries are all perennial. These streams are characterized by relatively uniform discharge throughout the year and by flood peaks of small amplitude and short duration. These characteristics result chiefly from (1) the relatively uniform distribution of precipitation through the year, (2) the highly absorptive character of the soil and substratum, (3) the gentle slope of the land surface, and (4) the large storage capacity of the ground-water reservoir.

The average monthly and yearly discharge of the four largest streams whose drainage basins are largely in the Huntington-Smithtown area is shown in table 4 . The total runoff of these streams from the project area averaged about 11 billion gallons a year (30 mgd) during the period of record. In estimating the average runoff for Cold Spring Creek, only the part of the drainage basin which lies in Huntington was used. The estimated average discharge of Mill Creek and Stony Hollow Run is based on occasional miscellaneous measurements since 1953. For the Nissequogue River a continuous record of streamflow has been maintained since 1943. Information on the flow of other streams in the project area is not available. These streams, however; probably do not contribute significantly to the total runoff, as their drainage basins are relatively small.

Most of the discharge of streams in the project area is derived from effluent seepage from the ground-water reservoir or groundwater runoff. Direct or overland runoff is normally insignificant 
except after periods of intense or heavy rainfall. For example, Legette (Paulsen, 1940, p. 529-552) estimated that overland runoff from the heavy rainfall which accompanied the hurricanes of September 1938 was only 1.4 to 2.3 percent of the total storm precipitation. These estimates were based on a study of an area in southern Iong Island where land slopes are relatively low and overland runoff would be at a minimum. Using a method similar to that of Leggette based on the relation of the total precipitation of a given storm to stream discharge, the author computed overland runoff in the Nissequogue River to be 3 to 4 percent of the rain which fell on the drainage basin during the hurricanes of August and September 1954. In this storm the somewhat higher overland runoff may be attributed to the relatively steeper land slopes which prevail in this basin.

At present (1960) little or no use is made of streams as a source of water for public supply and for industrial or domestic purposes. However, all streams in the project area are used considerably for esthetic and recreational purposes and for the propagation of fish and wildlife. For example, Cold Spring Brook provides water for the New York State Fish Hatchery located a short distance upstream from the head of Cold Spring Harbor, and three ponds on the stream provide recreational facilities (Sawyer, 1954, p. 20). The Nissequogue River, which is the largest stream on Long Island, was used extensively in the 19th century for milling and light navigation. At present, it is used almost exclusively for recreational purposes and for the conservation of fish and wildlife (Brice, 1952, p. 29). The Nissequogue is considered to be one of the best sport fishing streams of Long Island.

\section{CHEMICAL QUALITY}

Except in a few localities near the shoreline, the chemical quality of both surface and ground water is generally excellent. Concentrations of the common chemical constituents are relatively low (table 5) and well within the maximum limits of standards prescribed by the U.S. Public Health Service (1946) for potable water supplies. Some of these standards are given in parts per million (ppm), as follows:

\begin{tabular}{|c|c|c|c|}
\hline & Ppm & & $P p m$ \\
\hline Iron (Fe) and manganese & 03 & Sulfate $\left(\mathrm{SO}_{4}\right)$ & 250 \\
\hline Magnesium (Mg) & 125 & Desirable maximum & 500 \\
\hline Chloride (Cl) & 250 & Permitted maximum & 1,000 \\
\hline
\end{tabular}

Iron is present in most of the ground water but is generally in concentrations of less than $0.3 \mathrm{ppm}$. The maximum observed concentration was $1.5 \mathrm{ppm}$ in a water sample taken on April 30, 1959, 
TABLE 4.-Summary of average discharge of streams continuously or occasionally gaged in the Huntington-Smithtown area

[Figures furnished by Surface Water Branch, U.s. Geol. Survey]

\begin{tabular}{|c|c|c|c|c|c|c|c|c|c|c|c|c|c|c|c|}
\hline \multirow{2}{*}{ Stream } & \multirow{2}{*}{$\begin{array}{l}\text { Period of } \\
\text { record }\end{array}$} & \multicolumn{12}{|c|}{ Average discharge (cfs) } & \multirow{2}{*}{$\begin{array}{c}\text { A verage } \\
\text { discharge } \\
\text { for period } \\
\text { of record } \\
\text { (cfs) }\end{array}$} & \multirow{2}{*}{$\begin{array}{l}\text { A verage } \\
\text { yearly } \\
\text { runoff for } \\
\text { period of } \\
\text { record } \\
\text { (million } \\
\text { gallons) }\end{array}$} \\
\hline & & Jan. & Feb. & Mar. & Apr. & May & June & July & Aug. & Sept. & Oct. & Nov. & Dec. & & \\
\hline $\begin{array}{l}\text { Cold Spring Brook at Cold Spring } \\
\text { Harbor.. } \\
\text { Nisseguogue River near Smith- }\end{array}$ & \multirow{4}{*}{$\begin{array}{l}1950-59 \\
1943-59 \\
1953-59 \\
1953-59\end{array}$} & 4.7 & 4.9 & 5.0 & 5.1 & 4.9 & 4.7 & 4.6 & 4.9 & 4.6 & 4.6 & 4.9 & 4.9 & \multirow{3}{*}{$\begin{array}{r}4.9 \\
42.3 \\
23.1 \\
21.3\end{array}$} & \multirow{3}{*}{$\begin{array}{r}1412 \\
9,979 \\
731 \\
307\end{array}$} \\
\hline $\begin{array}{l}\text { town } \\
\text { Mill Creek }\end{array}$ & & 42.5 & 43.2 & 45.8 & $\mathbf{4 7 . 0}$ & 46.0 & 42:4 & 40.2 & 40.6 & 38.5 & 38.4 & 41.2 & 41.5 & & \\
\hline Stony Hollow Run. & & & $\cdots$ & $\ldots$ & $\cdots$ & - & -....- & [-- & 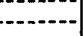 & 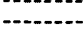 & 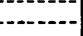 & & $\cdots$ & & \\
\hline Total .... & & & & & & & & & & & & & & 51.6 & $\overline{11,429}$ \\
\hline
\end{tabular}

1 A verage yearly runoff estimated for the part of the drainage basin which lies in Huntington (2.6 square miles of the total of about 7.3 square miles at the gaging station), Average discharge from curves of correlation (Sawyer, 1961).

TABLE 5.-Chemical analyses, in parts per million, of ground uater in the Huntington-Smithtown area

[Agency making analysis: USGS, U.S. Geol. Survey; USBS, U.S. Bur. Standards. Water-bearing unit: L, Lloyd sand member; M, Magothy(?) formation; P, Pleistocene [Agesits]

\begin{tabular}{|c|c|c|c|c|c|c|c|c|c|c|c|c|c|c|c|c|c|c|}
\hline Well & $\begin{array}{l}\text { Map } \\
\text { coordi- } \\
\text { nates }\end{array}$ & $\begin{array}{l}\text { Depth of } \\
\text { screen } \\
\text { (feet) }\end{array}$ & $\begin{array}{l}\text { Date of } \\
\text { collection }\end{array}$ & $\begin{array}{c}\text { Agency } \\
\text { making } \\
\text { analysis } 1\end{array}$ & $\begin{array}{c}\text { Water- } \\
\text { bearing } \\
\text { unit ? }\end{array}$ & $\begin{array}{l}\text { Silica } \\
\left(\mathrm{SiO}_{2}\right)\end{array}$ & $\begin{array}{l}\text { Iron } \\
(\mathrm{Fe})\end{array}$ & $\begin{array}{l}\text { Cal- } \\
\text { cium } \\
(\mathrm{Ca})\end{array}$ & $\begin{array}{l}\text { Magne- } \\
\text { sium } \\
(\mathrm{Mg})\end{array}$ & $\begin{array}{c}\text { So- } \\
\text { dium } \\
\text { (Na) }\end{array}$ & $\begin{array}{l}\text { Potas- } \\
\text { sium } \\
(\mathbf{K})\end{array}$ & $\begin{array}{c}\text { Bicar- } \\
\text { bonate } \\
\left(\mathrm{HCO}_{3}\right)\end{array}$ & $\begin{array}{c}\text { Sul- } \\
\text { fate } \\
\text { (SOt) }\end{array}$ & $\begin{array}{c}\text { Chlor- } \\
\text { ide } \\
\text { (Cl) }\end{array}$ & $\begin{array}{l}\text { Fluo- } \\
\text { ride } \\
\text { (F) }\end{array}$ & $\begin{array}{l}\mathrm{Ni}- \\
\text { trate } \\
\left(\mathrm{NO}_{3}\right)\end{array}$ & $\begin{array}{l}\text { Dis- } \\
\text { solved } \\
\text { solids }\end{array}$ & $\begin{array}{l}\text { Hard- } \\
\text { ness as } \\
\mathrm{CaCo}^{2}\end{array}$ \\
\hline 881. & \multirow{3}{*}{$\begin{array}{l}8 \mathrm{E} \\
9 \mathrm{E} \\
10 \mathrm{E} \\
10 \mathrm{E} \\
10 \mathrm{E}\end{array}$} & \multirow{3}{*}{$\begin{array}{c}488-588 \\
173-202 \\
713-728 \\
308-348 \\
553\end{array}$} & $\begin{array}{lr}\text { Oct. } & 10,1932 \\
\text { May } & 1,1934\end{array}$ & $\begin{array}{l}\text { USGS.- } \\
\text { UsGS:- }\end{array}$ & \multirow{3}{*}{$\begin{array}{l}\mathbf{L} \\
\mathbf{P} \\
\mathbf{L} \\
\mathbf{L} \\
\mathbf{M} \\
\mathbf{M} \\
\mathbf{M}\end{array}$} & 8.0 & $\begin{array}{r}0.02 \\
.01\end{array}$ & \multirow{3}{*}{$\begin{array}{l}5.0 \\
2.0 \\
2 \\
5 \\
2.0\end{array}$} & 0.9 & 40 & 0.8 & \multirow{3}{*}{$\begin{array}{r}28 \\
7 \\
15 \\
21 \\
20\end{array}$} & \multirow{3}{*}{$\begin{array}{l}2.0 \\
2.0 \\
.6 \\
1 \\
1.0\end{array}$} & \multirow{3}{*}{$\begin{array}{l}4.0 \\
5.0 \\
7 \\
8 \\
7.0\end{array}$} & 0.0 & \multirow[t]{3}{*}{$\begin{array}{l}0.3 \\
1.0\end{array}$} & \multirow{3}{*}{$\begin{array}{l}31 \\
36 \\
55\end{array}$} & \multirow{3}{*}{$\begin{array}{r}20 \\
8 \\
9 \\
20 \\
10\end{array}$} \\
\hline S49..- & & & Dec. 7,1933 & USBS.-.- & & 8 & .08 & & .9 & $7^{20}$ & -- & & & & & & & \\
\hline $\mathbf{8 5 1} \ldots$ & & & Oct. 10,1932 & Usuี̄̃.-. & & & & & & & & & & & & & & \\
\hline
\end{tabular}


from well S16137. Water samples from wells S27, S49, and S8251 also had iron concentrations of $0.35,0.45$ and $0.32 \mathrm{ppm}$, respectively. The median range and concentration of iron in the ground water of the project area are summarized in table 6. Manganese is found only in trace concentrations in the ground water. Generally, iron and manganese do not presently (1960) constitute a problem in the use of ground water for public supply or other purposes.

TABLE 6.-Iron concentration, chloride concentration, hardness as $\mathrm{CaOO}_{3}$ and variation in $p H$ of ground water in the Huntington-Smithtonon area, 1956-59

\begin{tabular}{|c|c|c|c|c|}
\hline & $\begin{array}{l}\text { Pleistocene } \\
\text { deposits }\end{array}$ & $\begin{array}{c}\text { Magothy(?) } \\
\text { formation }\end{array}$ & $\begin{array}{l}\text { Lloyd sand } \\
\text { member }\end{array}$ & $\begin{array}{l}\text { All } \\
\text { aquifers }\end{array}$ \\
\hline \multicolumn{5}{|c|}{ Iron concentration } \\
\hline $\begin{array}{l}\text { Number of analyses } \\
\text { Range in concentration } \\
\text { Median concentration }\end{array}$ & $\begin{array}{r}19 \\
0.00-1.5 \\
0.08\end{array}$ & $\begin{array}{r}19 \\
0.00-0.32 \\
0.04\end{array}$ & $\begin{array}{r}8 \\
0.00-0.60 \\
0.15\end{array}$ & $\begin{array}{r}0.00-1.5 \\
0.08\end{array}$ \\
\hline \multicolumn{5}{|c|}{ Chloride concentration } \\
\hline $\begin{array}{l}\text { Number of analyses } \\
\text { Range in concentration } \\
\text { Median concentration. }\end{array}$ & $\begin{array}{r}35 \\
1-26 \\
8\end{array}$ & $\begin{array}{r}18 \\
1-810 \\
6\end{array}$ & $\begin{array}{r}7 \\
2-1,700 \\
4\end{array}$ & $\begin{array}{r}60 \\
1-1,700 \\
7\end{array}$ \\
\hline \multicolumn{5}{|c|}{ Hardness as $\mathrm{CaCO}_{3}$} \\
\hline $\begin{array}{l}\text { Number of analyses } \\
\text { Range. } \\
\text { Median }\end{array}$ & $\begin{array}{r}20 \\
8-108 \\
24\end{array}$ & $\begin{array}{r}18 \\
7-36 \\
16\end{array}$ & $\begin{array}{r}9 \\
4-28 \\
8\end{array}$ & $\begin{array}{r}47 \\
4-108 \\
20\end{array}$ \\
\hline
\end{tabular}

\begin{tabular}{|c|c|c|c|c|}
\hline \multicolumn{5}{|c|}{ Variation in $\mathrm{pH}$} \\
\hline $\begin{array}{l}\text { Number of analyses. } \\
\text { Range } \\
\text { Median }\end{array}$ & $\begin{array}{r}20 \\
5.7-7.2 \\
6.3\end{array}$ & $\begin{array}{r}18 \\
5.7-7.2 \\
6.2\end{array}$ & $\begin{array}{r}6 \\
6.6 .8 \\
6.3\end{array}$ & $\begin{array}{r}44 \\
\text { 5. } 4-7.2 \\
6.3\end{array}$ \\
\hline
\end{tabular}

The median concentration of chloride in the ground water ranges from 4 to $8 \mathrm{ppm}$ (table 6). In the central part of the area the maximum observed chloride concentration was $26 \mathrm{ppm}$ on September 10, 1958, in well S16794. Chloride concentrations exceeding 100 ppm have been observed at several near-shore localities, however (fig. 12).

The hardness as $\mathrm{CaCO}_{3}$ of the ground water is generally less than $100 \mathrm{ppm}$. The median and the range of hardness are shown in table 6 . The water becomes progressively softer with depth. This softening probably can be attributed to ion exchange during downward percolation of water through clayey aquicludes.

The $\mathrm{pH}$ of the ground water ranges from 5.4 to 7.2 (table 6) and is generally less than 7.0. Because of this fact the water is some- 
what corrosive, and treatment for control of the $\mathrm{pH}$ may be needed at public-supply or industrial well installations.

The dissolved-solids content of the water is generally less than $150 \mathrm{ppm}$.

\section{TEMPERATURE}

Occasional temperature measurements of water from wells and streams in theHuntington-Smithtown area have been made by the U.S. Geological Survey and also by well drillers. The maximum and minimum temperatures of ground water observed in the project area are $72^{\circ}$ and $49^{\circ} \mathrm{F}$, respectively. The greatest seasonal and annual range in ground-water temperatures occurs in the shallow part of the ground-water reservoir at depths less than 50 feet below land surface. The observed range of temperature in this depth interval is from $50^{\circ}$ to $72^{\circ} \mathrm{F}$. At depths greater than 50 feet, the temperature ranges from only $49^{\circ}$ to $56^{\circ} \mathrm{F}$ and generally decreases with depth. For example, at well S16794, 45 feet deep, two observations indicated a range from $53^{\circ}$ to $62^{\circ} \mathrm{F}$. Seven temperature measurements taken at well S50 at Northport, 348 feet deep, indicated a range from $50^{\circ}$ to $51^{\circ} \mathbf{F}$. Three measurements at well S9 on West Neck, 570 feet deep, ranged from $56^{\circ}$ to $56.3^{\circ} \mathrm{F}$.

Several temperature measurements of water from streams in the project area were made by the U.S. Geological Survey on August 18-20, 1959. The water temperatures observed ranged from $59^{\circ}$ to $80^{\circ}$ and averaged $70^{\circ} \mathrm{F}$. Temperatures taken at several points along the Nissequogue River ranged from $59^{\circ}$ to $72^{\circ} \mathrm{F}$. The air temperature at the time of observation ranged from $78^{\circ}$ to $93^{\circ} \mathrm{F}$. The water temperature in the river is related to air temperature, to stream velocity, and to volume of ground-water inflow at or near the site of the temperature measurement. The location of surface-water measuring points and the temperatures observed are given in figure 12.

\section{CONTAMINATION}

Although the natural chemical quality of the water is generally excellent, local contamination of the water supply has resulted from the activities of man. The sources of contamination in areas inland from the shoreline are domestic and industrial wastes, fertilizers, and salts used for deicing and dust control on roads. In near-shore areas, sources of contamination are salt water pumped from tidewater for washing sand and gravel and sea water which has encroached the aquifers adjacent to the shorelines.

The most useful chemical criteria for contamination are the chloride and nitrate ions, whose presence in the water in greater-thannormal concentrations is indicative of the source and the degree of 


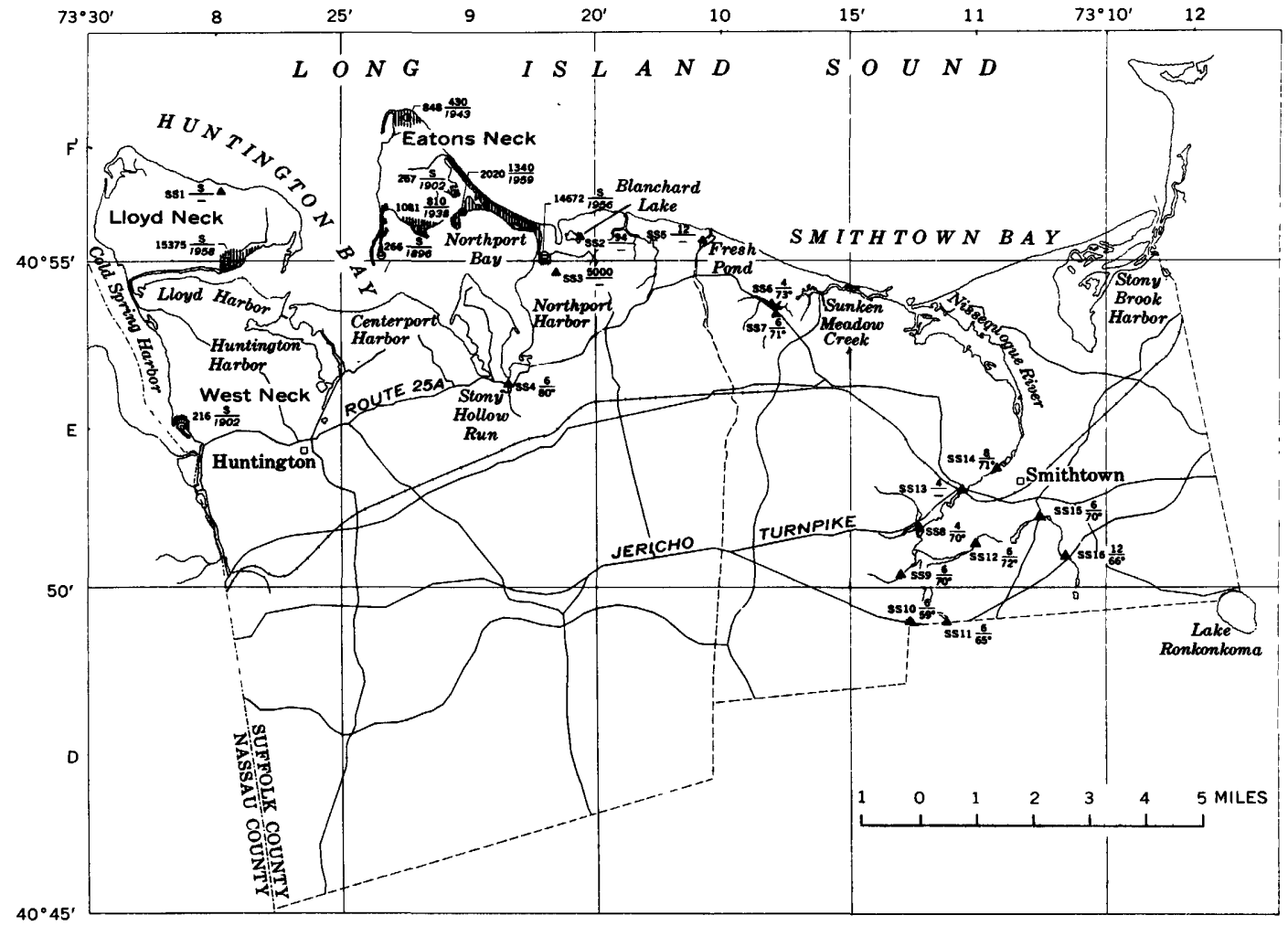

EXPLANATION

- $240 \frac{430}{10+3}$

Upper Pleistocene deposits -

Magothy(?) formation

Loyd sand member

Ground-water sampling point Symbol indicates source of water. Well number: upper figure is chloride concentration in parts per analysis or of report; "S", driller reported sally water

$$
\Delta \text { ss9 } \frac{6}{10^{\circ}}
$$

Surface-water sampling point Sampling-point number and symbol upper figure is chloride concentration in ports per million; lower figure is temperature of water in degrees Fohrenheit

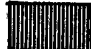

Area underlain by ground water containing more than 100 parts per million of chloride

FIGURw 12.-Map showing surface-water sites at which temperature and ehloride determinations were made August 18-20, 1959, and wells containing water of high chloride content. 
contamination. The water from wells and streams normally contains less than $15 \mathrm{ppm}$ of chloride and $5 \mathrm{ppm}$ of nitrate; greater concentrations of these constituents are generally indicative of contamination.

Except for the sewage disposal systems of Kings Park State Hospital and of the villages of Huntington and Northport which discharges into tidewater, practically all domestic sewage and liquid industrial waste are disposed of in cesspools, septic tanks, leaching basins, and sewage treatment filter beds from which contaminating effluent ultimately reaches the water table and thence moves into streams. The effects of this type of contamination are only slightly perceptible in most of the ground and surface water of the project area at present (1960). These effects, however, are expected to increase as population and home density increases and if central sewage disposal systems are not installed. The highest chloride concentrations observed in the ground water of the central part of the project area were $22 \mathrm{ppm}$ in well S1811 and $26 \mathrm{ppm}$ in well S16794. These wells tap water at depths of 10 and 45 feet, respectively. These higher-than-normal chloride concentrations are attributed to contamination from cesspool effluent. Also, during the past 15 years, the increasing use (Task Group Report, 1959) of synthetic detergents (syndets) for household use and the disposal of these in cesspools and in septic tanks has resulted in a small but perceptible concentration of syndet residual, commonly the surfactant (wetting agent) alkyl benzene sulfonate (ABS), in the shallow ground water and in streams. Concentrations of $1 \mathrm{ppm}$ or greater of syndets cause foam to form on water when it is agitated (Flynn, 1958). In higher concentrations, syndets impart a taste to water that is disagreeable to sensitive individuals. The toxicity of syndets to the human system is not yet well established. Syndets, at least in trace concentrations, are probably present in some shallow wells and in some streams. The concentrations are generally only barely detectable by available analytical techniques. For example, among analyses of water samples from 36 shallow wells in the village of Smithtown by C. W. Lauman \& Co., Inc., in 1959, only one sample contained as much as $0.1 \mathrm{ppm}$ of syndet. Additional analyses for syndets were made by the New York State Department of Health on samples taken on April 30, 1959, from well S16137 at South Huntington and on July 1, 1958, from wells S15514 and S15515 at East Northport. The syndet concentration in well S16137 was less than $0.03 \mathrm{ppm}$ and in wells S15514 and S15515 was less than $0.05 \mathrm{ppm}$.

Fertilizers used to increase crop yields are also a source of contamination to the shallow ground water. For example, potassium chloride, ammonium nitrate, calcium sulfate, and other inorganic 
salts applied to the land in fertilizer form are partly dissolved by downward percolating water and ultimately increase, at least locally, the concentration of these salts in the ground water. This source of contamination has never been a serious problem in the project area, and it is gradually decreasing with suburban development and the consequent reduction in cultivated and cropped land.

Sodium chloride for winter-ice control and calcium chloride for dust control on highways are used in substantial quantity in Suffolk County; combined they probably total on the order of about 0.8 pound per year per linear foot of highway (Hoffman and Spiegel, 1958, p. 16). These salts largely dissolved by infiltrating water ultimately reach the water table and contaminate the shallow ground water. As the volume of salts introduced in this form is diluted by a far greater volume of ground water, the resulting contamination from this source is relatively insignificant, except perhaps locally.

Local contamination of ground- and surface-water supplies in nearshore areas may result from the practice of using salt water pumped from adjacent salt-water bodies for washing and sorting sand and gravel at quarries. Commonly, the spent wash water is discharged on the land surface or wasted into artificial ponds above sea level. Seepage or overflow from such salt-water ponds results in local contamination of the ground water and streams. This practice is common in sand and gravel quarries in the Northport area adjoining Long Island Sound and Northport Bay. Blanchard Lake near Northport (pl. 1), which intersects the water table and is nominally fresh, is occasionally contaminated in this manner. For example, in August 1956 the lake water contained $19 \mathrm{ppm}$ of chloride, but in February 1959 the chloride concentration was $94 \mathrm{ppm}$. This increase was apparently caused by salt water used for sand and gravel washing and discharged on the land surface in the area south of the lake. The salt water moved into the lake presumably by overland flow, by ground-water flow, or by both means.

In the Huntington-Smithtown area, sea-water encroachment is apparently not a general problem nor does available evidence suggest that encroachment is in progress at present (1960), except perhaps locally on Eatons Neck. However, if the trend toward sharply increasing withdrawals (fig. 11) continues as in the past decade, salt-water tongues may eventually be expected to invade, at least locally, the coastal parts of the ground-water reservoir, and possibly to contaminate near-shore wells. Existing wells that are particularly susceptible are located in and near centers of moderately heavy withdrawal near the southern extremities of Cold Spring, Huntington, Centerport, and Northport Harbors (pl. 6). In 1960, the chloride concentrations in water pumped from wells in these areas was less 
than $16 \mathrm{ppm}$. Apparently, the developed aquifers beneath and adjacent to these salt-water embayments are at least partly protected by beds of relatively impervious clay and silt in the Pleistocene and Cretaceous deposits and in similar harbor-bottom deposits of Recent age. Eventually, however, increasing withdrawals and consequent reduction in fresh-water head in these areas could result in local sea-water encroachment. Concurrent dredging in the harbors and removal, wholly or partly, of the protective cover of harbor-bottom deposits would also facilitate encroachment.

Salt-water encroachment and contamination have occurred locally on Eatons Neck and may be aggravated if withdrawals substantially increase over those currently (1960) prevailing. This possibility was demonstrated by a pumping test conducted in July 1958 at well S1081. Prior to pumping, a chloride concentration of $505 \mathrm{ppm}$ was reported in the water from the well. After a 34-hour interval of pumping, the chloride concentration of the water increased to $810 \mathrm{ppm}$. Chloride concentrations exceeding $500 \mathrm{ppm}$ also are reported in well S848 on Eatons Neck after long periods of pumping, although the average concentration is less than $500 \mathrm{ppm}$. Two other wells, S3554 and S1039, located near well S848, but somewhat farther inland, yield water in which the chloride concentration is 35 and $4.9 \mathrm{ppm}$, respectively. All these wells are screened in the shallow aquifer in the Magothy (?) formation. The progressive landward decrease in the chloride concentration in the ground water substantiates the conclusion that contamination takes place from the seaward direction.

Chloride concentrations exceeding $100 \mathrm{ppm}$ have been observed in the ground water of several areas fringing the shores of Eatons, Lloyd, and West Necks. This ground water probably became salty under natural conditions. Pumping, however, may induce further encroachment toward the interior parts of these peninsulas, as has been observed at wells S848 and S1081. Areas underlain by such salty ground water are shown on figure 12. The extent of these areas is approximated from available data and possibly may be greater or smaller than indicated. In some instances areas underlain by salty water have been inferred from wells in which drillers reported salty water. Around much of the coastal fringe of Eatons Neck, salty ground water occurs at varying depths in the groundwater reservoir. At well S2020 (pl. 4) a chloride concentration of $1,700 \mathrm{ppm}$ was measured in a water sample from the Lloyd sand member. This sample probably represents the quality of the water near the base of the Lloyd at a depth of 605 feet below sea level. It is therefore inferred that salty water may occur in the Lloyd sand member beneath much, if not all, of the interior part of Eatons Neck. Salty water has also been found in the upper Pleistocene deposits 
and in the Magothy (?) formation in wells S266, S267, S848 and S1081 in the coastal zone of Eatons Neck (fig. 12). Apparently in the interior part of Eatons Neck, fresh ground water occurs only in the upper Pleistocene deposits and in the Magothy(?) formation, possibly as a fresh-water lens floating on deeper salty water (pl. 4).

Along the southeastern shore of Lloyd Neck, salty ground water was reportedly obtained from well S15375 at a depth of 231 feet in the Magothy(?) formation. However, well S16918, drilled about 200 feet north of this well, is screened at a depth of 145-150 feet in fresh water in the Magothy (?) formation. Salty ground water also probably occurs at shallow depth beneath tidal marshes fringing the northwestern part of Lloyd Neck. With these exceptions, the ground water in the upper Pleistocene deposits and Magothy (?) formation is probably fresh in most of Lloyd Neck. Water from wells S1794 and S4466, in the Lloyd sand member beneath the southwestern part of Lloyd Neck, contained chloride concentrations of only 2 and $4 \mathrm{ppm}$, respectively, in 1959. Presumably water in the Lloyd sand member is also fresh under most, if not all, of Lloyd Neck.

A small zone of salty ground water occurs in the shallow aquifer on the western short of West Neck, adjoining Cold Spring Harbor (fig. 12). Here, salt water is reported at well S216 (Veatch and Bowman 1906, p. 293) from 14 to 100 feet below land surface. Fresh water was found beneath a layer of clay, which lies at a depth of 100-158 feet. Apparently, the occurrence of salty water at this site is limited to coarse upper Pleistocene deposits underlying a small sand spit.

\section{CONCLUSIONS}

The ground-water reservoir underlying the Huntington-Smithtown area is recharged naturally by an estimated average of $147 \mathrm{mgd}$ of water whose sole source is precipitation. In 1957, an average of about $14.7 \mathrm{mgd}$ was pumped from this reservoir. About $10.5 \mathrm{mgd}$ of the gross withdrawal in 1957 was returned artificially to the reservior so that a net of only about $4.2 \mathrm{mgd}$ was used consumptively or wasted. Thus, the net withdrawal is relatively small in comparison with the estimated average rate of natural recharge. Moreover, water levels in observation wells for which long-term records are available have remained relatively stable during the past two decades and do not suggest any downward trend attributable to pumping at present (1960) rates.

A very substantial increase in the net rate of withdrawal from the ground-water reservoir could be sustained if the new centers of pumping were properly located with respect to existing well fields. The distribution of existing centers of moderately heavy withdrawal in 1960, shown in plate 6, suggests that new wells and well fields should generally be at least 2 or more miles inland (south) from 
tidewater and a mile or more from existing installations to minimize effects of interference. Also, withdrawals exceeding those in 1960 from existing wells and well fields near tidewater, particularly from wells near the southern extremities of Cold Spring and Huntington Harbors, and in the vicinity of Centerport and Northport Harbors (pl. 6) are not advocated. Increased draft from these well fields could eventually lead to local overdevelopment and to contamination by sea-water encroachment from these salt-water embayments. On the other hand, the present draft on the ground-water reservoir in the central and southern parts of Huntington, and particularly in Smithtown, is relatively light. Consequently, these parts are potential areas for development of supplies from new wells and well fields.

At present (1960), the danger of sea-water encroachment is more immediate on Eatons Neck than elsewhere in the project area. This area is nearly surrounded by open salt-water bodies and apparently is underlain by salty ground water in most of the intermediate aquifer and in all the deep aquifer. Fresh water sustained by local recharge apparently occurs only as a lens in the shallow aquifer and possibly in the upper part of the intermediate aquifer. There is some evidence of local encroachment at near-shore wells on Eatons Neck, and if pumping were increased, the degree of contamination would probably also intensify.

Salt water used for washing sand and gravel is locally wasted into ponds or on the land surface at pits and quarries near tidewater, such as those north of Northport. This practice may result in local contamination of fresh ground water near the points of disposal.

Contamination of the shallow ground water of Long Island and Suffolk County by synthetic detergents and other domestic waste has been a problem since the end of World War II and appears to be becoming increasingly serious owing to rapid suburban growth and development. Although available data suggest that the problem has not yet (1960) become very serious in the Huntington-Smithtown area, adequate provisions should be made to cope with it in the future. Partial solutions would include (1) development and marketing of nonstable synthetic detergents which degrade completely in their movement through the soil and in ground water, (2) the location of new wells for public-water supply in zones where the density of population and industrial development is low and likely to remain so in the future, (3) the setting aside of specific zones of restricted industrial and residential development to protect the environs of future public water-supply well installations, (4) the withdrawal of public-water supplies from wells in the deeper part of the Magothy (?) formation in zones where population and industrial development are already relatively dense, and (5) construction of sanitary sewer systems in 
areas currently containing a high density of population or industry and likely to grow in the future.

Geologic and hydrologic knowledge of the ground-water reservoir in 1960, although substantial, is far from complete. In particular, information is needed on the pressure heads, water quality, and hydraulic properties of deeper parts of the Magothy(?) formation (intermediate aquifer) and of the Lloyd sand member (deep aquifer). The need for this information is particularly critical on Lloyd and Eatons Necks and in the shoreline areas, where the Lloyd may constitute the only or chief available source of fresh water. In inland areas, such information on the Lloyd is needed to evaluate more closely the paths of water movement and also to evaluate the availability of water in the deeper parts of the ground-water reservoir. From an economic standpoint and because of its relative immunity to contamination from domestic and industrial waste, the deeper part of the Magothy(?) formation, in particular the basal gravelly zone, needs to be more closely appraised with respect to its potential for future water development. This zone is only lightly pumped but no doubt would sustain many wells of relatively high yield. The needed information on both the Magothy(?) and the Lloyd would be provided by test drilling at selected sites and under close supervision so as to obtain a maximum of geologic and hydrologic data.

To monitor seasonal and annual changes in ground-water storage, an adequate program of water-level measurements in observation wells should be maintained on a continuing basis. To detect seawater encroachment, water in wells and well fields near tidewater should be sampled periodically for chloride content. To observe and to judge future trends in contamination of the ground-water reservoir by domestic and industrial waste, water samples from both shallow and deep wells should be analyzed periodically for syndets, chloride, and nitrate. Occasionally, more comprehensive chemical analyses of water samples from representative wells and from streams should be made.

Ground-water conservation presently practiced by means of diffusion wells and recharge basins, in which used cooling water pumped from wells and runoff from precipitation is returned to the ground, is well conceived and should be continued and expanded wherever physical and economic conditions permit. The maintenance of these structures should also be improved wherever feasible to permit optimum ground-water recharge. In addition, as a measure of water conservation as well as of storm-runoff disposal, the construction of recharge basins and diffusion wells should be linked wherever practicable to construction of new roads, buildings, and parking lots. 
Map coordinates: Number and letter Indicate grid square on map, figure 2 Map coordinates: Number and letter indicate grid square on map, figure 2 .
Owner: WD, Water District; SCWA, Suffolk County Water Authority; USGS,
United States Geological Survey.

Altitude of reference point: Reference point is land surfa at most wells except of a foot; others interpolated to nearest 10 feet from topographic maps.

Water-yielding unit: uP, upper Pleistocene deposits; $\mathrm{Ma}$, Mannetto gravel; $\mathbf{M}, \mathbf{M a}$ gothy(?) formation; L, Lloyd sand member of the Raritan formation; Pu, Pleistocene deposits undifferentiated. indicated in "Remarks" column. Altitude by Spirlt levelling given to nearest tenth

Water level: Measurement reported by driller given to nearest foot. Measurements by Geographical Survey given to nearest tenth of a foot.

Use: A, abandoned; Dom, domestic; Ind, Industrial, Institutional or estate; Irr, Irrigation; O, observation; PS, Public supply; T, test hole.

Bull GW -4 (Uil Commission Power and Control Commission Bull. of -9 (Ropublished in New York Water Well log published in New York Water Power and Control Commission Bull is w31 (New York State Water Power and Control Comm., 1952). d, Well number as published in U.S. Geol. Survey Prof. Paper 44 (Veach and Bowman, 1906).

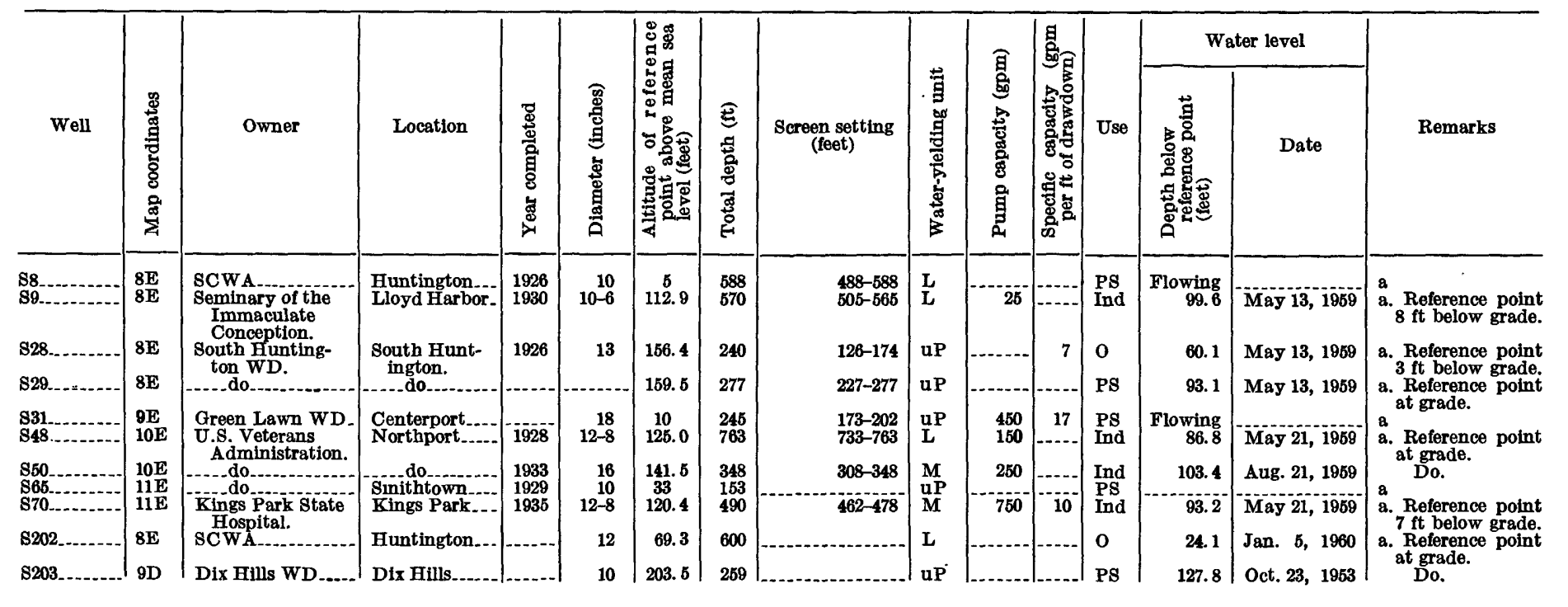




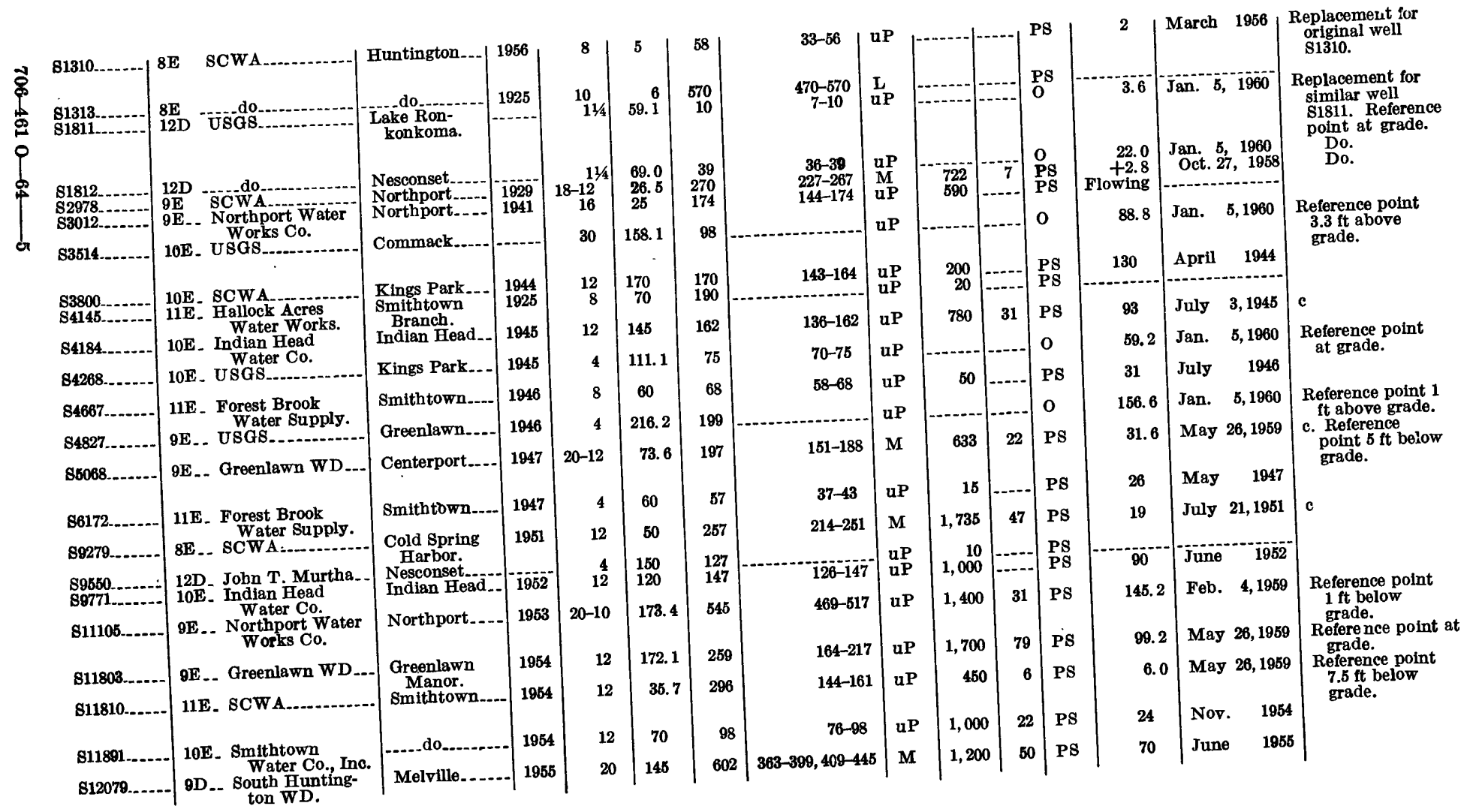


TABLE 7.-Records of selected wells in the Huntington-Smithtown area-Continued

[See fig. 2 for location of wells]

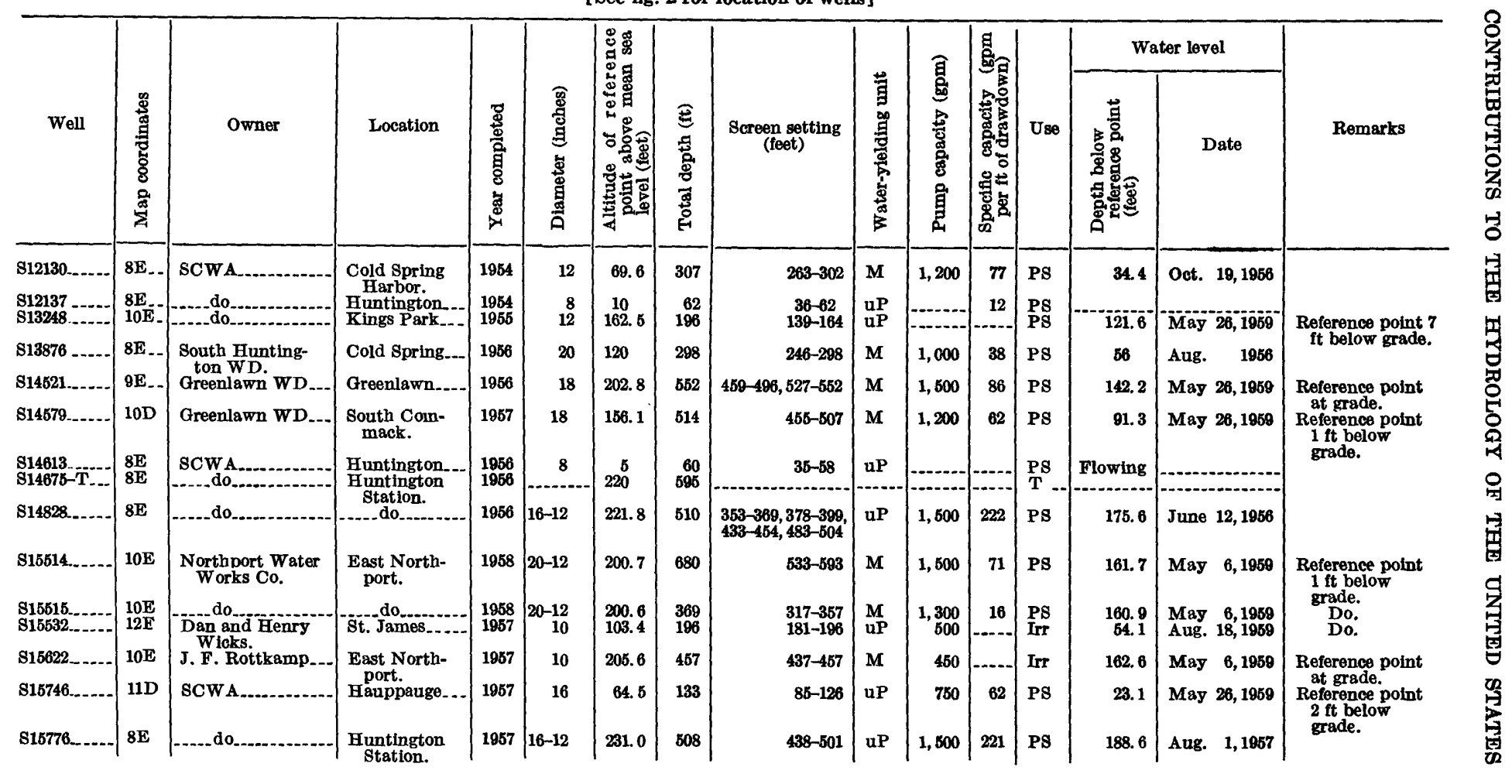




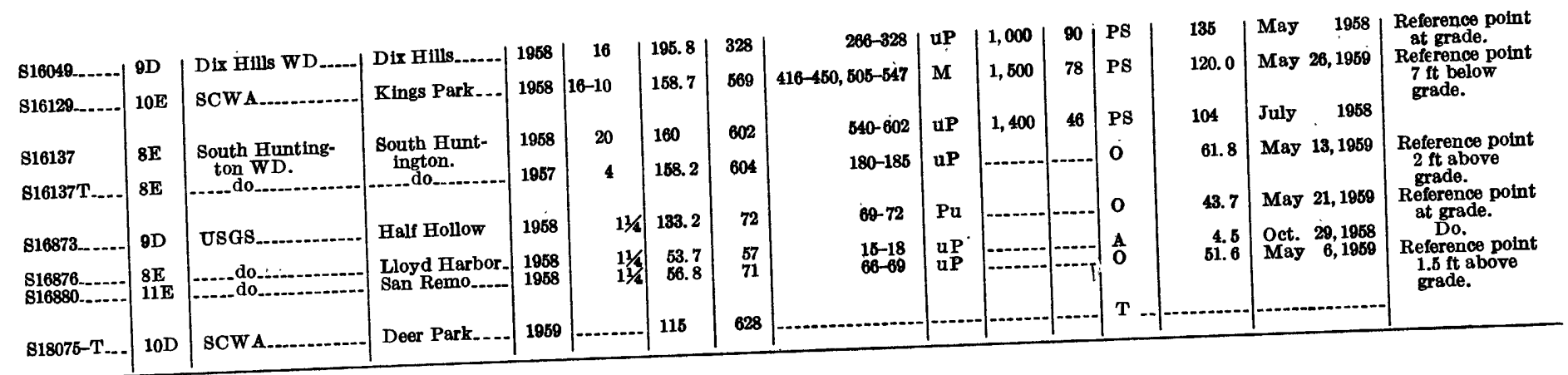




\section{REFERENCES CITED}

Brice, H. D., 1952, Progress report on streamflow investigations in Suffolk County, Long Island, New York, 1903, 1942-47: U.S. Geol. Survey openfile rept., $144 \mathrm{p}$.

Fleming, W. L. S., 1935, Glacial geology of central Long Island: Am. Jour. Sci., v. 30, p. 216-238.

Flynn, John M., and others, 1958, Study of synthetic detergents in ground water : Am. Water Works Assoc. Jour., v. 50, no. 12, p. 1551-1562.

Fuller, M. L., 1914, the geology of Long Island, New York: U.S. Geol. Survey Prof. Paper 82, 231 p.

Hoffman, J. F., 1959, Ground-water utilization, Suffolk County, Long Island, New York: Jour. Hydraulics Div., HY 7, Am. Soc. Civil Engineers Proc., p. 25-41.

Hoffiman, J. F., and Spiegel, S. J., 1958, Chloride concentration and temperature of water from wells in Suffolk County, Long Island, New York, 1928-53: New York State Water Power and Control Comm. Bull. GW-38, $55 \mathrm{p}$.

Meyer, A. F., 1944, The elements of hydrology: New York, John Wiley and Sons, Inc., $522 \mathrm{p}$.

New York State Water Power and Control Commission, 1952, Record of wells in Suffolk County, New York: New York State Water Power and Control Comm. Bull. GW-31, 2d Supp., 137 p.

Paulsen, Carl B., 1940, Hurricane floods of September 1938: U.S. Geol. Survey Water-Supply Paper 867, 562 p.

Perlmutter, N. M., and Crandell, H. C., 1959, Geology and ground-water supplies of the south-shore beaches of Long Island, New York: Annals of the New York Acad. of Sci., v. 80, art. 4, p. 1060-1076.

Roberts, C. M., and Brashears, M. L., Jr., 1945, Record of wells in Suffolk County, New York: New York State Water Power and Control Comm. Bull. GW-9, 1st Supp., 155 p.

Sawyer, R. M., 1954, Progress report on streamflow investigations in Suffolk County, Long Island, New York, 1948-52: U.S. Geol. Survey open-file rept., $127 \mathrm{p}$.

1961, Progress report on streamflow investigations in Suffolk County, Long Island, New York, 1953-57: U.S. Geol. Survey open-file rept., 159 p.

Suter, R., deLaguna, Wallace, and Perlmutter, N. M., 1949, Mapping of geologic formations and aquifers of Long Island, New York; New York State Water Power and Control Comm. Bull. GW-18, 212 p.

Swarzenski, W. V., 1961, Hydrogeology of northwestern Nassau and northeastern Queens Counties, Long Island, New York: U.S. Geol. Survey open-file rept. $247 \mathrm{p}$.

Task Group Report, 1959, Effects of synthetic detergents on water supplies: Am. Water Works Assoc. Jour., v. 51, no. 10, p. 1251-1254.

Theis, C. V., and others. 1954, Estimating transmissibility from specific capacity : U.S. Geol. Survey Ground Water Note no. 24, 11 p.

Thompson, D. C., Wells, F. C., and Blank, H. R., 1937, Recent geologic studies on Long Island with respect to ground-water supplies: Econ. Geology, v. 32 , no. 4, p. $451-470$.

Thornthwaite, C. W., and Holzman, Benjamin, 1939, The determination of evaporation from land and water surfaces: Monthly Weather Review, U.S. Department of Agr., v. 67, no. 1, p. 4-11. 


\section{HYDROGEỌLOGY OF HUNTINGTON-SMITHTOWN AREA, N.Y. D65}

U.S. Geological Survey, 1938, Records of wells in Suffolk County, New York: New York State Water Power and Control Comm. Bull. GW-4, 137 p. U.S. Public Health Service, 1962, Drinking water standards: Federal Register, Mar. 6, p. 2152-2155.

Veatch, A. C., and Bowman, Isaiah, 1906, Well records on Long Island, p. 116-337, in Veatch, A. C., Slichter, C. S., Bowman, Isaiah, Crosby, W. O., and Horton, R. E., Underground water resources of Long Island, New York: U.S. Geol. Survey Prof. Paper 44, 394 p.

Weiss, Lawrence, 1954, Foraminifera and origin of the Gardiners clay (Pleistocene), eastern Long Island, New York: U.S. Geol. Survey Prof. Paper 254-G, 163 p.

Wenzel, L. K., 1942, Methods for determining permeability of water-bearing materials, with special reference to discharging-well methods; with a section on direct laboratory methods, and bibliography on permeability and laminar flow by V. C. Fishel; U.S. Geol. Survey Water Supply Paper 887, $192 \mathrm{p}$.

Wiggin, Thomas H., 1957, Report on a comprehensive plan for the development and distribution of the available water supply of Suffolk County, Long Island, New York: Suffolk County Water Authority, 145 p.

Williams, G. R., and others, 1940, Natural water loss in selected drainage basins: U.S. Geol. Survey Water-Supply Paper 846, 62 p. 



\section{INDEX}

[Italic page numbers indicate major references]

\begin{tabular}{|c|c|}
\hline e & ( \\
\hline bstract. & Glacial deposits \\
\hline wledgme & Glacioflu \\
\hline ..................... & Glaciolacustrine deposits..... \\
\hline lkyl benzene sulfonate (ABS) & Gneiss ................... \\
\hline quiclude & Granite.................... \\
\hline quifer & Greenlawn \\
\hline See also Deep aquifer; Intermediate aqui- & Greenlawn Manor.............. \\
\hline & er \\
\hline artesian & harge of. \\
\hline rtesian pressure.................. & ion........................ \\
\hline - & movement.................. \\
\hline phy.................... & perched_................. \\
\hline Blanchard Lake.................. & reservoir \\
\hline Buried valleys................... & rawals \\
\hline ................. & \\
\hline t Harbor $\ldots . . . . .6,29,33,38,42,48,55,58$ & Hills......... \\
\hline quality of water & Harbor Hill end moraine. ........... 6, 10, 25, 28 \\
\hline Shloride. & rminal moraine $\ldots \ldots \ldots \ldots . . . . .21,25,26$ \\
\hline lay & - \\
\hline (n) & 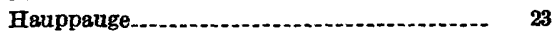 \\
\hline g Brook & Huntington..... $3,29,38,42,48$ \\
\hline Ig Creek. & Bay \\
\hline ing Harbor $\ldots 6,11,18,29,40,48,55,57,58$ & Harbor_..... 6, 29, 33, 38, 42, 48, 55, 58 \\
\hline 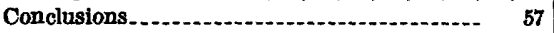 & Station \\
\hline lon of ground water. & nithtown area. \\
\hline ontamination & $12,13,18,23,25,27,48$ \\
\hline prevention of & $30,35,38$ \\
\hline deposits $\ldots \ldots \ldots \ldots$ & $\ldots 9,10,26$ \\
\hline roted. & ampage. \\
\hline 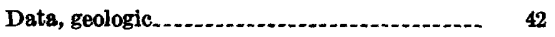 & (n) \\
\hline fer & uifer_............ 28, $\$ S, 35,40,42$ \\
\hline 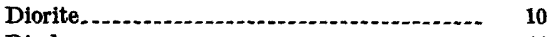 & 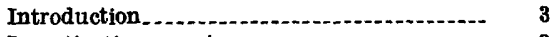 \\
\hline (n) & 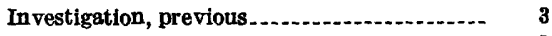 \\
\hline 19,23 & purpose of \\
\hline water, disposal of & 49,51 \\
\hline Drainage._._. & lules_-_._. \\
\hline Drawdown & Irrigation.... \\
\hline Duck Island & vel_................... \\
\hline 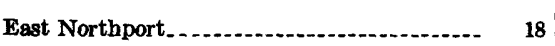 & $x^{\prime}$ \\
\hline $11,28,29,33,36,37,40,55,56,57,58$ & 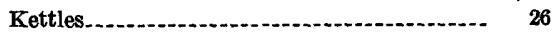 \\
\hline vapotranspiration. & Kings Park \\
\hline 8 & koma \\
\hline , contamination by.... & 12,13 \\
\hline ossils. & and \\
\hline Clay _............. $9,20,22,28,26$ & $6,11,12,28,29,33,36$ \\
\hline
\end{tabular}


Lloyd sand member of Raritan Formation . . - D9, $11,12,13,21,36,47,59$

Location of area.

3

Long Island Lighting $\mathrm{Co} . \ldots . . . . . . . . . . . . . . . .7$

Long Island Sound

$6,45,55$

Magothy formation........ $11,12,18,14,18,19,21$,
$26,28,29,33,47,57,59$

Manganese

Mannetto gravel_................. 9, 19, 20, 23, 25, 28

Marme beds_........................... 8, 11, 27

Melville_..................................... 18

Metamorphic rocks...................... 9, 10, 26

Mill Creek................................. 7, 45, 48

Mineola, N.Y

Monmóuth Group.

Nassau County.

New York State Water Resources Commission $5,6,46,47$

Nissequogue River......... 6, 7, 29, 33, 41, 45, 48, 49

Nissequogue River valley.

Nitrate. $52 ; 54$

Northport. . . . .

buried valley ............................... 21

Northport Bay_............................. 40, 55

Northport Harbor............ 6, 29, 33, 38, 42, 48, 58

Perennial streams

Permeability, coefficients of

pH 51,52

Physiography.

Piezometric divide

surface.

Pleistocene deposits........... 9, 19, 20,21, 22, 23, 25, $33,35,38,41,42$ $26,27,28,29,44,57$

Pliocene(?) deposits

9,19

Population

7

Precipitation .............. 8, 30, 57

Public-supply wells

Pumpage.

$13,23,45,46,47$

Pyrite

Queens County
Raritan formation upper clay member of

See also Lloyd sand member.

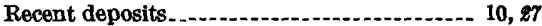

Recharge _....................................... 40

Ropkonkoma terminal moraine..... 6, 7, 10, 25, 26

Salt-water encroachment................... 56

Sandstone

Schist............................................ 10

Shallow aquifer.............. $28,30,35,41,42,56,57$

Silty clay .................................... 23

Smithtown................... 3, 18, 21, 22, 27, 38

Smithtown Bay......................... 6

South Commack.

South Huntington........................... 23

South Huntington Water District well field 1.. $\quad 35$

Stony Brook Harbor . . ...................... 30

Stony Hollow Run .

Sunken Meadow Creek. ................ 7

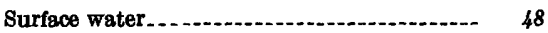

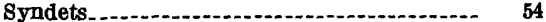

Temperature .................... 8, 62

Transmissibility, coefficients of

Unconsolidated deposit_.................... 9

Upper Cretaceous series...................... 11

U.S. Public Health Service, water standards_- $\quad 49$

Water-bearing units........................ 27

Water-level measurements. ................... 42, 59

Water table ................................... 30

Water velocity, formula ........................ 44

Wells, drawdown ............ 18, 23

logs.

numbering system........................

public supply

pumpage......................... 13, 23, 45, 46, 47

West Hills.

West Neck._.................................. 56,57

Wisconsin glacial stage......................... 20, 22

13 Withdrawals, by major use.................. 48 